\title{
Article \\ Glass Cullet as Additive to New Sustainable Composites Based on Alumina Binder
}

\author{
Aleksandra Powęzka ${ }^{1, *\left(\mathbb{D}, \text { Paweł Ogrodnik }^{2} \mathbb{D} \text {, Jacek Szulej }\right.}{ }^{3} \mathbb{D}^{\mathbb{D}}$ and Mariusz Pecio $^{1}$ \\ 1 Faculty of Security Engineering and Civil Protection, Main School of Fire Service, 01-629 Warsaw, Poland; \\ mpecio@sgsp.edu.pl \\ 2 Institute of Security Engineering, Main School of Fire Service, 01-629 Warsaw, Poland; pogrodnik@sgsp.edu.pl \\ 3 Faculty of Civil Engineering and Architecture, Lublin University of Technology, 20-618 Lublin, Poland; \\ j.szulej@pollub.pl \\ * Correspondence: apowezka@sgsp.edu.pl
}

check for

updates

Citation: Powęzka, A.; Ogrodnik, P.; Szulej, J.; Pecio, M. Glass Cullet as Additive to New Sustainable Composites Based on Alumina Binder. Energies 2021, 14, 3423. https: / / doi.org/10.3390/ en14123423

\section{Academic Editors: Rafael}

Sánchez Sánchez and

Abdul-Ghani Olabi

Received: 14 March 2021

Accepted: 28 May 2021

Published: 10 June 2021

Publisher's Note: MDPI stays neutral with regard to jurisdictional claims in published maps and institutional affiliations.

Copyright: (c) 2021 by the authors. Licensee MDPI, Basel, Switzerland. This article is an open access article distributed under the terms and conditions of the Creative Commons Attribution (CC BY) license (https:/ / creativecommons.org/licenses/by/ $4.0 /)$.
Abstract: The article investigated the possibility of reusing heat resistant glass cullet to improve the mechanical properties of high-temperature composites. This is an excellent recycled aggregate that may be used as a substitute for alumina cement, and for fine natural aggregate in the production of concrete based on hydraulic binder. The experimental programme comprised of strength testing conducted on $40 \times 40 \times 160 \mathrm{~mm}$ cuboidal samples. The model mixture was modified by filler that comprised glass recyclate, amounting to $5 \%, 10 \%$, and $15 \%$ of the mass of gravel and cement. Given the degree of glass grounding, use was made of two fractions, $0 / 4$ and $0 / 0.125 \mathrm{~mm}$. Six modified mixtures were produced. Tests were then carried out on their selected physical and mechanical properties as well as the impact of temperature, topography, and chemical composition exerted on the composite. Next, the progress and development of compressive strength and flexural strength after 14 and 28 days of curing were studied. Results showed that concrete with a $5 \%$ content of glass dust had a maximum compressive strength at the level of $85.1 \mathrm{MPa}$. Results also showed that concrete (Zk.I.5) heated at a temperature of $500{ }^{\circ} \mathrm{C}$ had a $46 \%$ higher compressive strength when compared to basic concrete (Z.I.0). The results show that it is possible to use the described components to obtain a composite that meets requirements imposed on structural materials used in construction engineering.

Keywords: recycling; glass cullet; waste glass powder; recycled aggregates; alumina cement; cement composite; mechanical properties; microstructure

\section{Introduction}

Glass has been used for many years and in various fields, including optics, the construction industry, and transport. Glass waste (among others packaging items, i.e., broken or damaged dishes, glasses, or crystal products) form 7-10\% of all waste deposited in landfills. Glass recycling helps limit the usage of sand, limestone, soda, and water (by up to 50\%) and energy (up to 30\%). This in turn reduces emissions released into the atmosphere. In Poland, approximately 30\% of glass packaging items are re-melted to obtain cullet. For comparison, elsewhere in the world, in such a way, on average $80-90 \%$ jars and bottles are processed. Every tonne of recycled glass cullet conserves $800 \mathrm{~kg}$ of sand, $250 \mathrm{~kg}$ of soda ash, and $180 \mathrm{~kg}$ of limestone dust. Glass recycling contributes to reducing the volume of landfills [1,2].

Glass waste totalled 5\% of global solid municipal waste generated in 2016 [3]. In that some year, the glass recycling coefficient ranged from $9 \%$ in Turkey to $98 \%$ in Slovenia and Belgium. In Europe, in 2017, this index amounted to $71.48 \%$ [4].

Glass is produced of glass sand (source of silica $\mathrm{SiO}_{2}$ ), borax (source of glass former $\mathrm{B}_{2} \mathrm{O}_{2}$ ), sodium and potassium feldspar (source of $\mathrm{Al}_{2} \mathrm{O}_{3}$ ), sodium carbonate, limestone, etc. Glass used in the construction industry contains approximately $70-72 \% \mathrm{SiO}_{2}, 15 \% \mathrm{Na}_{2} \mathrm{O}$, $10 \% \mathrm{CaO}$, and as $\mathrm{MgO}, \mathrm{Al}_{2} \mathrm{O}_{3}$, along with ingredients that enhance glass properties or the 
production process. One of the operations in the glass production process is melting of the set at a temperature of $1400-1500{ }^{\circ} \mathrm{C}$; the molten mass is then clarified and optimised [5]. On the one hand, glass is an extremely brittle material, but on the other hand, it is equally durable and may survive thousands of years intact. It does not lose its properties even if it is repeatedly processed. Given its unique properties, it is a highly ecological and economic raw material that is wholly suitable for processing. Although recycling of cullet is a serious and complex undertaking, it deserves attention. Various researchers are inspired to seek innovative applications, which need to be modern, fulfil performance requirements, and contribute toward environmental protection. The recyclate needs to be free from contamination that could potentially pollute the final product. This makes selective collection of glass waste so important.

Numerous studies [6-18] have proven the suitability of using recycled materials in the production process of ceramics, binders, mortar, concrete, plaster, bituminous materials, etc. In the testing, use is being made of various types of cullet, including car glazing [19], soda-lime glass from containers [20-22], glass from technological lines of the pharmaceutical industry [23-25], cathode ray tubes for TV sets and computer screens [26,27], float glass from window glazing [28], glass from fluorescent lamps [29], glass from heat resistant dishes [30-32] and mirrors, safety glass, crystal glass, and colourless, green, and brown packaging glass [33-37]. Studies are underway in regards to the usage of concrete rubble [38] for the production of "green concrete".

Waste cullet deposited in landfills does not become decomposed [39,40]; it is a perfect secondary raw material, resistant to mould and humidity. Crushed recyclate may be used in concrete as a substitute for cement, sand, and coarse aggregate. Purified and crushed recyclate are used in several different fields. In the construction industry, it is considered a perfect addition to façade plaster or a semi-product in building mortars (after processing to glass powder). It is also used for the production of foam glass, ceramic mass, or glass fibres. It offers a perfect alternative for natural soils, or natural aggregate used for the production of cement composites. It is also used with success as a binder for the stabilisation of embankments and road subgrades [41,42]. After crushing to powder form (dust fraction), waste glass may be used in the production of decorative tiles and catalyser carriers. Cullet may also be used to produce microbeads for producing reflective paints. The powder phase of crushed glass may be used in concrete as Pozzolanic material [43].

Managing glass waste is an action that arises from the currently-binding Directive of the Council of Europe 91/689/EEC, which is directly aimed at protecting the environment. When designing cement composite, cullet may be added to concrete in the form of fibre, powder, or grain. The addition of glass consisting of fibres [17,44-51] enhances the parameters of concrete. Cement composites achieve better strength and become resistant to environmental factors (humidity, solar radiation, thawing, and freeing). If cement is replaced with crushed cullet (to dust fraction) [35-37], the obtained concrete offers better workability, increasing the compressive and tensile strength after an extended curing period. If the cullet is to be used as a substitute for fine aggregate (sand) [33,34,52], it is necessary to take into consideration the type of glass used. If a 10-30\% addition of cullet is made, a decrease in strength takes place, equalling to $10-25 \%$ as compared to the executed control trial [53]. Scientists also point to the possibility of introducing recyclate to concrete mixture as a substitute for coarse aggregate [54-58]. From an economic viewpoint, this solution seems advantageous. It does not require a large work input, as in the case of fibres or crushing to powder form.

An extensive review of the literature shows that diverse types of waste are used as substitutes of aggregate in the production of concrete [59,60]. To date, no analyses have been carried out in regards to the recycling of used heat resistant dishes in concrete with alumina concrete. The paper presents the possibility of using heat resistant glass cullet, obtained from crushed glass dishes, for the production of concrete. This emphasises the innovative approach to the issue and the interdisciplinary nature of work. An analysis 
was performed on selected properties of concrete, particularly the impact of recyclate on physical, mechanical, and structural properties.

The study is a continuation of works commenced in articles [30-32], related to the re-use of glass waste. Given the obtained strength parameters and taking into account the necessity of waste management, glass recycling is a feasible solution in the production of mortar and concrete. If results of those studies are deployed in market operations, this may contribute to reduce the amount of waste deposited in landfills.

\section{Materials}

\subsection{Concrete Mixture}

Composite was generated from mixing alumina binder with filler consisting of natural and recycled aggregate and water. Heat resistant glass cullet was used as a substitute of traditional aggregate and cement (variable parameter). Control mixture (Z.I.0) was produced along with 6 series modified by glass recyclate. The composition of concrete mixture is presented in Tables 1 and 2.

Table 1. Weight and volume composition of the Zk.I mixture, $\mathrm{kg} / \mathrm{m}^{3}$.

\begin{tabular}{ccccc}
\hline Component & Z.I.0 & Zk.I.5 & Zk.I.10 & Zk.I.15 \\
\hline Alumina cement & 488 & 488 & 488 & 488 \\
Sand 0/2 mm & 562 & 562 & 562 & 562 \\
Gravel 2/8 mm & 833 & 791.35 & 749.7 & 708.05 \\
Glass aggregate & - & 42 & 83 & 125 \\
0/4 mm & - & - & - & - \\
Glass powder & - & 196 & 196 & 196 \\
0/0.125 mm & 196 & 0.40 & 0.40 & 0.40 \\
Water & 0.40 & & \\
w/c & & & & \\
\hline
\end{tabular}

${ }^{1}$ Water-cement coefficient, ratio of effective water mass to the contents of cement mass in concrete mixture $(-)$.

Table 2. Weight and volume composition of mixture Zc.I, $\mathrm{kg} / \mathrm{m}^{3}$.

\begin{tabular}{ccccc}
\hline Component & Z.I.0 & Zc.I.5 & Zc.I.10 & Zc.I.15 \\
\hline Alumina cement & 488 & 463.6 & 439.2 & 414.8 \\
Sand 0/2 mm & 562 & 562 & 562 & 562 \\
Gravel 2/8 mm & 833 & 833 & 833 & 833 \\
Glass aggregate & - & - & - & - \\
0/4 mm & & & & 73.2 \\
Glass powder & - & 24.4 & 48.8 & 196 \\
0/0.125 mm & 196 & 196 & 196 & 0.47 \\
Water & 0.40 & 0.42 & 0.45 & \\
w/c & & & & \\
\end{tabular}

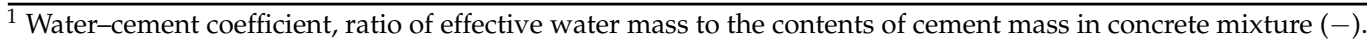

Cullet was added to the concrete mixture, in amounts equalling to $5 \%, 10 \%$, and $15 \%$ of the coarse aggregate mass, limiting the amount of gravel (Zk.I.5-Zk.I.10-Zk.I.15), and in amounts equalling to $5 \%, 10 \%$, and $15 \%$ of the cement mass, limiting the used amount of cement (Zc.I.5-Zc.I.10-Zc.I.15). An assumption was made of a constant ratio of the $\mathrm{w} / \mathrm{c}$ coefficient at the level of 0.40 for mixtures modified by glass aggregate $0 / 4 \mathrm{~mm}$. This proportion was used to maximally limit the contents of capillary pores in the structure of the cement matrix [61]. Mixtures modified by glass powder were characterised by different $\mathrm{w} / \mathrm{c}$ ratio, amounting to $0.42,0.45$, and 0.47 . A low water-cement ratio allows obtaining better strength and tightness and, consequently, long-term durability. In her study, Kucharska [62] assumed the w/c coefficient as a basic criterion by which concrete may be broken down into a common type and a fully-valuable one. 


\subsection{Cement}

The concrete mixture was produced with the use of GÓRKAL 70 high-alumina cement (Górka Cement Sp. z o.o., Trzebinia, Poland). The declared performance properties of cement are outlined in Tables 3-5.

Table 3. Chemical composition of alumina cement, $\%$.

\begin{tabular}{ccccc}
\hline $\mathbf{A l}_{\mathbf{2}} \mathbf{O}_{\mathbf{3}}{ }^{\mathbf{1}}$ & $\mathrm{CaO}^{\mathbf{1}}$ & $\mathbf{S i O}_{\mathbf{2}}{ }^{\mathbf{1}}$ & $\mathbf{F e}_{\mathbf{2}} \mathbf{O}_{\mathbf{3}}{ }^{\mathbf{1}}$ & $\mathbf{N a}_{\mathbf{2}} \mathbf{O}+\mathbf{K}_{\mathbf{2}} \mathbf{O}^{\mathbf{1}}$ \\
\hline $69-71$ & $28-30$ & $<0.5$ & $<0.3$ & $<0.5$ \\
\hline textsuperscript1 The contents were determined by the XRF or classical method.
\end{tabular}

Table 4. Mechanical and hydraulic properties of alumina cement ${ }^{1}$.

\begin{tabular}{cccc}
\hline $\begin{array}{c}\text { Bending Strength after } \\
\mathbf{2 4} \mathbf{~ h}, \mathbf{M P a}\end{array}$ & $\begin{array}{c}\text { Compressive Strength } \\
\text { after } \mathbf{2 4} \mathbf{~ h}, \mathbf{M P a}\end{array}$ & $\begin{array}{c}\text { Commencement of } \\
\text { Binding Time, min }\end{array}$ & $\begin{array}{c}\text { End of Binding Time, } \\
\text { min }\end{array}$ \\
\hline$>5$ & $<30$ & $>160$ & $<240$ \\
\hline${ }^{1}$ Composition of the mixture: French sand $(1350 \mathrm{~g})$, cement $(450 \mathrm{~g})$, and water $(225 \mathrm{~g})$. &
\end{tabular}

Table 5. Special properties of alumina cement.

\begin{tabular}{|c|c|c|c|}
\hline $\begin{array}{l}\text { Specific Surface } \\
\text { Area according to } \\
\text { Blaine, } \mathrm{cm}^{2} / \mathrm{g}\end{array}$ & $\begin{array}{l}\text { Typical Ordinary } \\
\text { Flame Resistance, sP }\end{array}$ & Density, $\mathrm{g} / \mathrm{cm}^{3}$ & Bulk Density, g/cm ${ }^{3}$ \\
\hline $4000-4500$ & $\geq 158$ & 3.0 & 1.1 \\
\hline
\end{tabular}

Alumina cement is characterised by high contents of $\mathrm{Al}_{2} \mathrm{O}_{3}$ and a stable phase composition with a domination of the crystalline phase. The basic phase consists of the calcium monoaluminate $\mathrm{CA}$, which is accompanied by dicalcium aluminate (grossite) $\mathrm{CA}_{2}$, with accompanying phases being $\mathrm{C}_{12} \mathrm{~A}_{7}, \alpha \mathrm{A}$. Concrete produced on the basis of alumina cement has many applications due to its physicochemical properties. Depending on the composition-its strength (at low and high temperatures) and colour change. White alumina cement is characterised by considerable purity and very good flame resistance; it may be used at a temperature of $1560{ }^{\circ} \mathrm{C}$ and gain high compressive resistance after a short time. The phase contents (\% by mass of cement) of $\mathrm{CA}_{2}$ in the cements rose from $30 \%$ at $1350{ }^{\circ} \mathrm{C}$ to $60 \%$ at $1450{ }^{\circ} \mathrm{C}$, whilst the 'free' $\mathrm{Al}_{2} \mathrm{O}_{3}$ content correspondingly declined from $20 \%$ to $5 \%$ [63]. In white aluminium cement, high temperature resistant $\mathrm{CA}_{6}$ is a hexagonal phase often occurring with $\alpha-\mathrm{Al}_{2} \mathrm{O}_{3}$ at a high temperature. $\mathrm{CA}_{6}$ is, presently, not hydraulic at ordinary temperatures, and normally only hydrates to any appreciable extent under hydrothermal conditions far above $100{ }^{\circ} \mathrm{C}$.

Due to the significantly higher hydration heat than for Portland cement, it can be used at a temperature of $-10^{\circ} \mathrm{C}$.

In addition to temperature extremes, it is sulphate-resistant, because of the lack of $\mathrm{CH}$ when hydration arises. The reason for the high resistance to sulphates, as well as sea water and chlorides, is not clear. George [64] reports that this is likely due to the very low permeability of the alumina cement slurries.

Alumina cement with $70-80 \% \mathrm{Al}_{2} \mathrm{O}_{3}$ content is also used for decorative purposes because it contains small, negligible amounts of ferrite $\mathrm{C}_{4} \mathrm{AF}$; they do not interfere with the whiteness of these cements where they are desired for aesthetic reasons.

\subsection{Aggregate}

The composite was prepared using a mixture of natural and recycled aggregate. The used gravel had a grading fraction of 2/8 mm (Zakład Produkcji Kruszyw Szumno Sp. J., Szumowo, Poland), ordinary sand from the Vistula with a fraction of $0 / 2 \mathrm{~mm}$ (PolBot Kruszywa S.A., Warsaw, Poland), and glass recyclate (Termisil S.A. Glassworks, Wołomin, Poland) having varied grinding levels. The glass was crushed in a crusher and then ground in a ball grinder to obtain fine aggregate with a grading of $0 / 4 \mathrm{~mm}$, and glass powder 
with a grading of $0 / 0.125 \mathrm{~mm}$. When selecting secondary raw material in the first place, economic and physical reasons were taken into consideration. Properties of cullet obtained from damaged glass dishes are presented in Table 6.

Table 6. Properties of glass obtained from TERMISIL S.A. glassworks.

\begin{tabular}{cc}
\hline Component & Requirements \\
\hline Transformation temperature, ${ }^{\circ} \mathrm{C}$ & 535 \\
Temperature of dilatometric softening, ${ }^{\circ} \mathrm{C}$ & 635 \\
Lower annealing temperature, ${ }^{\circ} \mathrm{C}$ & 520 \\
Upper annealing temperature, ${ }^{\circ} \mathrm{C}$ & 550 \\
Permissible working range, ${ }^{\circ} \mathrm{C}$ & $-40 \div 300$ \\
Density at $20{ }^{\circ} \mathrm{C}, \mathrm{g} / \mathrm{cm}^{3}$ & 2.23 \\
Hydrolytic stability of glass grains at the & $\mathrm{HGB} 1$ \\
temperature of $98{ }^{\circ} \mathrm{C}$ & \\
Average coefficient of linear thermal expansion & $3.55 \times 10^{-6}$ \\
$\left(30{ }^{\circ} \mathrm{C} ; 300{ }^{\circ} \mathrm{C}\right), \mathrm{K}^{-1}$ & 80 \\
$\mathrm{SiO}_{2}, \%$ & 4 \\
$\mathrm{Na}_{2} \mathrm{O}, \%$ & 1 \\
$\mathrm{~K}_{2} \mathrm{O}, \%$ & 13 \\
$\mathrm{~B}_{2} \mathrm{O}_{3}, \%$ & 2 \\
$\mathrm{AL}_{2} \mathrm{O}_{3}, \%$ & \\
\hline
\end{tabular}

Obtained and crushed aggregate from glass waste is presented in Figure 1.

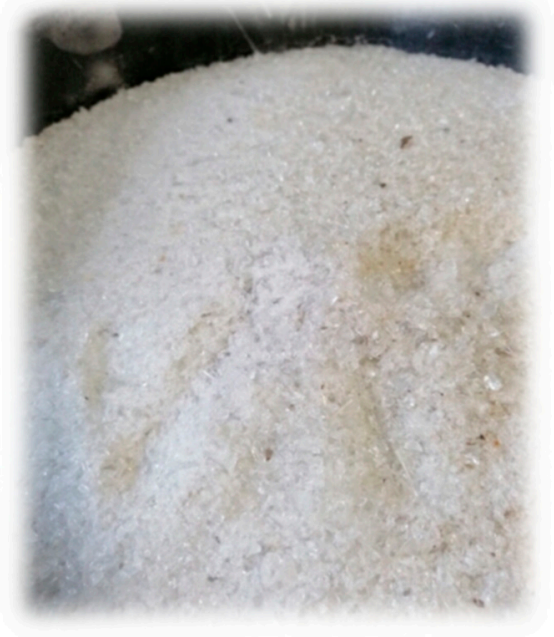

(a)

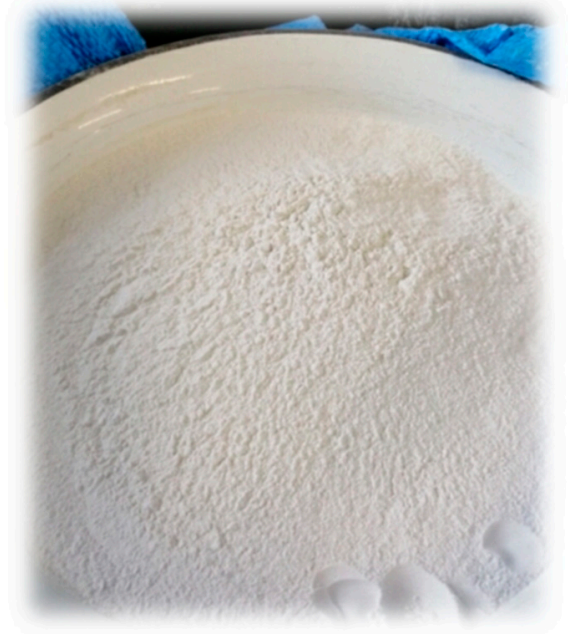

(b)

Figure 1. Recycling cullet aggregate: (a) fine aggregate with a fraction of $0 / 4 \mathrm{~mm}$; (b) glass powder with a fraction of $0 / 0.125 \mathrm{~mm}$.

\subsection{Water}

Make-up water for the production of the planned mixture may be obtained directly from the water supply line.

\section{Methods}

The main objective of the study was to evaluate the feasibility of reusing heat-resistant cullet obtained from broken glass dishes for the production of unconventional concrete types. Pilot testing comprises strength tests, a semi-quantitative analysis of the chemical composition aimed at obtaining a distribution map of elements, and an analysis of topography and phase composition of the planned composite. Moreover, a spot chemical analysis was performed of the material. The impact of high temperature on properties of the planned concrete was evaluated. The cullet was separated into fractions containing 
particles of different sizes. The recyclate was sieved through a set of sieves and the grading was then tested.

\subsection{Grading Analysis}

To determine the size and dimensions of particles of glass recyclate, a grading composition test was carried out using the sieve method, in line with guidelines contained in the standard EN 933-1:2012. The recyclate was sieved and catalogued in a mechanical way to divide it into particular fractions with given diameters of the tested particles. After weighing of subsequent grading classes remaining on the given sieve, percentages of particular fractions in the tested sample were determined in relation to the whole. A grading curve was devised that presented the type of aggregate and its specific properties.

\subsection{Strength of Hardened Concrete}

Properties of hardened composite were determined on the basis of conducted strength tests. The tensile strength in a three-point bending scheme $f_{c f}$ was determined on cuboidal concrete bars with the dimensions of $40 \times 40 \times 160 \mathrm{~mm}$. For needs of the tests, the samples were set-up with their concreted surfaces perpendicular to the direction of the applied load. Then, the halves of the samples obtained after the flexural strength test were used to determine the compressive strength $f_{\mathcal{c}}$ [65]. The tests were carried out after the lapse of 14- and 28-day curing periods, according to the standard PN-EN 12390-5:2011 in the Advantest 9 hydraulic press (Controls, Warsaw, Poland).

\subsection{Tests of Concrete at Elevated Temperature}

The $40 \times 40 \times 160 \mathrm{~mm}$ beams were dried in a laboratory drier KC-100/200 (Zalmed, Warsaw, Polska) until constant mass was achieved, at a temperature of $105 \pm 5{ }^{\circ} \mathrm{C}$. Four sets of samples were taken for the research. The samples were heated at temperatures of $200{ }^{\circ} \mathrm{C}, 400{ }^{\circ} \mathrm{C}, 600{ }^{\circ} \mathrm{C}$, and $800^{\circ} \mathrm{C}$ in a special furnace-PK $1100 / 5$ (Thermolab S.C., Warsaw, Poland) furnished with powered heating compartments. The thermal process was programmed with the use of dedicated ThermoPro software. The temperature in the furnace remained for $30 \mathrm{~min}$ until completion of the heating process, which was monitored using a NiCr-Ni thermocouple attached to the control sample. The temperature distribution was illustrated by the standard curve "temperature-time". Each set was baked at a different temperature, then cooled and tested separately. The results were compared with reference samples. All heated elements were subjected to measurements of tensile strength in a trial of bending and compressive strength.

\subsection{Studying Morphology and Elemental Composition in SEM and EDS}

Material tests of the execution and of the top layer of the composite, including primarily morphology and the elemental composition, the scanning electron microscope (SEM) type FEG Quanta 250 was used (FEI, Hillsboro, OR, USA) with an attachment for X-ray microanalysis in the EDS mode (EDAX, Mahwah, NJ, USA). The research material was obtained from fragments of concrete bars remaining from strength tests. Samples for SEM tests were powder painted and fixed to the grip with the use of a carbon binder. The samples were coated with a thin carbon layer (approximately $50 \mu \mathrm{m}$ ) as a result of cathode spraying.

\section{Results and Discussion}

\subsection{Sieve Analysis of the Waste Cullet}

For comparison, results of the granulometric analysis were applied onto a semilogarithmic grid, obtaining a sieving curve (Figure 2). When determining the composition of mixtures, aggregate and aggregate composition, attempts were made to select them, ensuring that they were contained between grading curves and that they had the smallest voids between particles. Recommendations contained in relevant applicable standards 
were taken into consideration in this respect. Pursuant to the curve obtained from testing, a calculation was made of diversity and curvature indices.

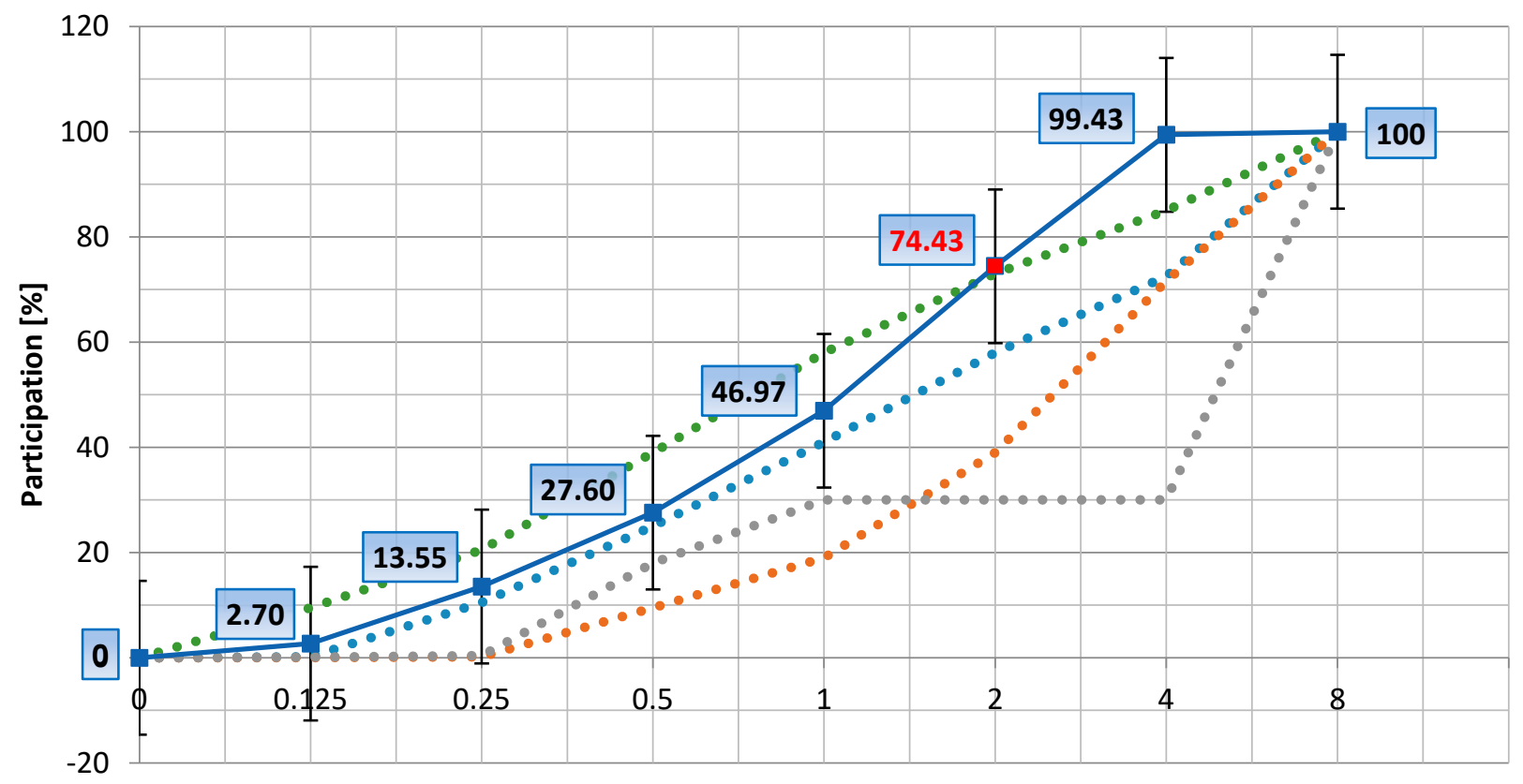

Fraction [mm]

-... Upper curve A

-.... Middle curve B

-... Bottom curve C

.... Discontinuous curve D

Glass cullet curve

(a)

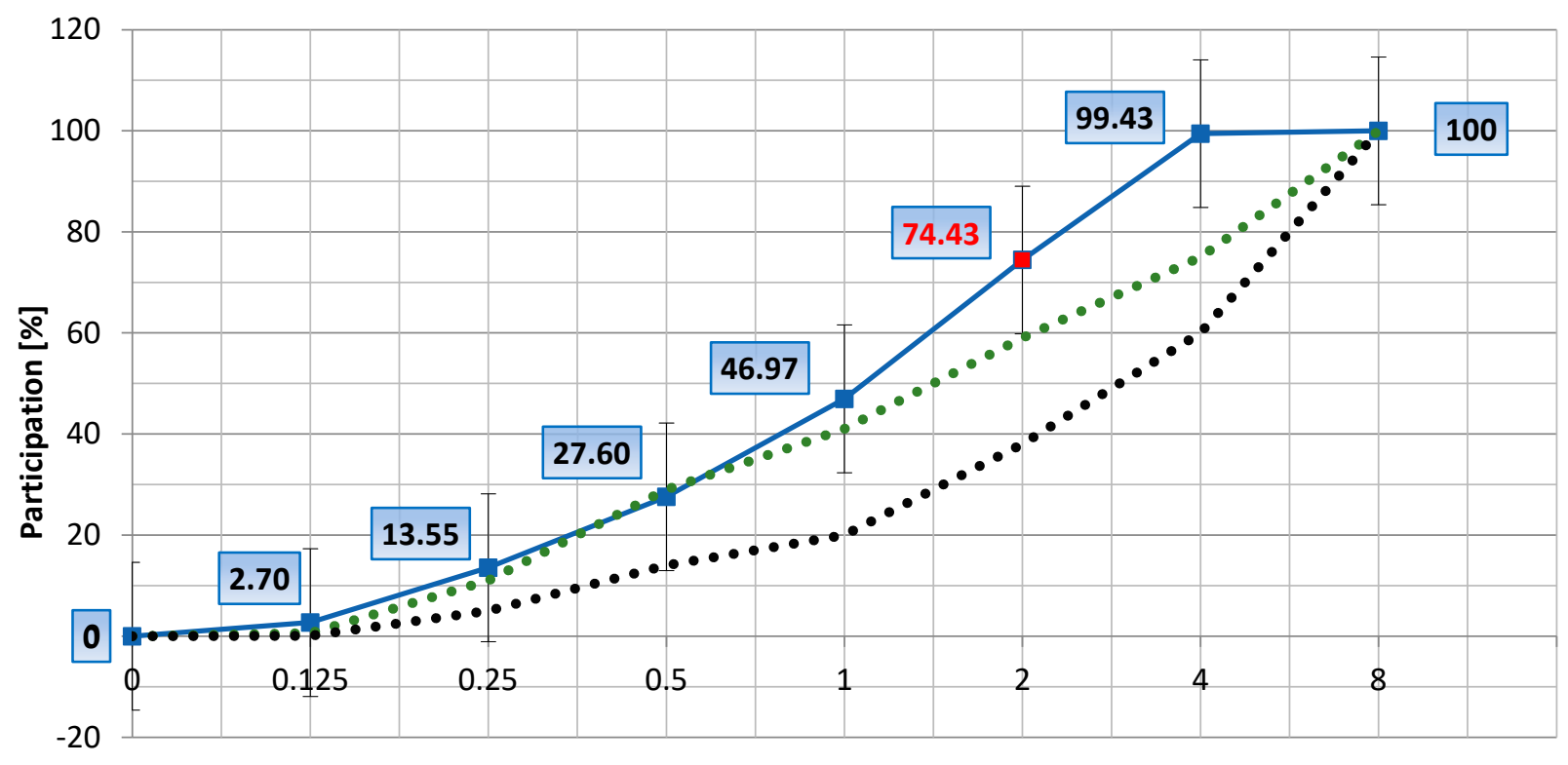

Fraction [mm]

$\longrightarrow$ Series $1 \quad \cdots$ U. Upper curve $1 \quad \cdots$ Bottom curve 2

(b)

Figure 2. Grading curve of used recyclate as compared to the standard good grading field: (a) DIN 1045-2; (b) PN-B 06250.

The cullet curve (Figure $2 b$ ) was not contained within the area of the limiting sifting 
curves (upper and lower ones). The recyclate failed to meet standard requirements of particularly good grading. The recyclate curve was over the upper limiting curve. The ground cullet was too coarse. However, that does not discriminate recyclate as an additive to concrete. Glass aggregate appeared much better after its application onto the grid of standard curves (Figure 2a). The area between the curves was determined as a good grading zone. Limiting curves contained in the standard DIN 1045-2:2014 made it possible to allow for the majority of concrete types, while limiting curves determined by the standard PN-B 06250 were characterised by a more extensive range of application.

To allow the delimiting of properties of aggregate composition, the sand content (PP) of glass cullet was determined, which amounted to $74.43 \%$, and this conformed to suggestions that may be found in literature sources [66] for a mixture with particles not larger than $8 \mathrm{~mm}$. The sand content was of considerable importance, assuring the required workability to the mixture. Aggregate having a sand content equal to $45-60 \%$ is suitable for application in vibro-pressable mixtures with a moist or dense plastic consistency, such as paving setts, in elements with no reinforcing, or with sparse reinforcing, which have a simple and uncomplicated shape of the section [8].

The obtained summation curves for particular types of aggregate were used to determine substitute diameters of grain (reliable diameter $\mathrm{d}_{10}$, diameter $\mathrm{d}_{30}$, and average diameter $\mathrm{d}_{60}$.), which constituted $10 \%, 30 \%$, and $60 \%$, respectively of the aggregate mass. Two parameters were calculated to characterise grading: uniformity coefficient (degree of uniformity) $\mathrm{C}_{U}$ and the coefficient of grading curvature $\mathrm{C}_{\mathrm{C}}$. Definitions of the parameters are described by Formulas (1) and (2). The above mentioned values are presented in Table 7.

$$
\begin{gathered}
C_{U}=\frac{d_{60}}{d_{10}}, \\
C_{C}=\frac{d_{30}^{2}}{d_{60} \cdot d_{10}} .
\end{gathered}
$$

Table 7. Grading indices of glass cullet.

\begin{tabular}{ccccc}
\hline $\mathbf{d}_{10}, \mathbf{m m}$ & $\mathbf{d}_{30}, \mathbf{m m}$ & $\mathbf{d}_{60}, \mathbf{m m}$ & $\mathbf{C}_{\mathbf{U}}$ & $\mathrm{C}_{\mathbf{C}}$ \\
\hline 0.21 & 0.56 & 1.37 & 6.53 & 1.11 \\
\hline
\end{tabular}

Indicator $C_{U}$ is a measure of inclination of the sieving curve. The uniformity coefficient for glass aggregate is 6.53 , while the curvature coefficient is 1.11. As per the classifications available in the literature sources, the studied recyclates are with several fractions [67], well-graded [68-71] and fine fractions that fill out the pores between larger particles.

\subsection{Analysis of Results Obtained from Strength Tests}

Laboratory strength testing was performed on cuboidal concrete bars with dimensions of $40 \times 40 \times 160 \mathrm{~mm}$. Changes of sample strength were executed by variations of the recipe of concrete mixtures. The samples were produced in accordance with guidelines contained in the standard PN-EN 206-1:2003. Laboratory tests were conducted at the temperature of $20^{\circ} \mathrm{C}$ after 14 and 28 days from demoulding of the samples. The composite was also tested after heating to temperatures of $200^{\circ} \mathrm{C}, 500{ }^{\circ} \mathrm{C}$, and $800^{\circ} \mathrm{C}$ after 28 days of curing.

The results of the conducted tests, including the statistical processing, which comprised the determination of average sizes, standard deviations, and variability indices, are shown in Tables 8-12. 
Table 8. Basic statistical parameters of concrete flexural strength.

\begin{tabular}{ccccccc}
\hline Concrete & $\begin{array}{c}\text { Flexural } \\
\text { Strength after } \\
\text { 14 Days, } \\
\text { MPa }\end{array}$ & $\begin{array}{c}\text { Standard } \\
\text { Deviation, } \\
\mathbf{M P a}\end{array}$ & $\begin{array}{c}\text { Variability } \\
\text { Index, } \\
\mathbf{\%}\end{array}$ & $\begin{array}{c}\text { Flexural } \\
\text { Strength after } \\
\mathbf{2 8} \text { Days, MPa }\end{array}$ & $\begin{array}{c}\text { Standard } \\
\text { Deviation, } \\
\mathbf{M P a}\end{array}$ & $\begin{array}{c}\text { Variability } \\
\text { Index, } \\
\mathbf{\%}\end{array}$ \\
\hline Z.I.0 & 11.9 & 0.2 & 1.65 & 11.9 & 0.6 & 5.31 \\
\hline Zk.I.5 & 10.5 & 0.9 & 8.48 & 11.2 & 0.3 & 2.85 \\
Zk.I.10 & 11.2 & 1.3 & 11.07 & 11.0 & 1.0 & 9.28 \\
Zk.I.15 & 11.8 & 0.8 & 6.72 & 10.7 & 0.5 & 4.58 \\
\hline Zc.I.5 & 12.0 & 0.7 & 5.81 & 11.7 & 0.3 & 2.73 \\
Zc.I.10 & 11.5 & 0.2 & 1.48 & 11.6 & 0.7 & 6.23 \\
Zc.I.15 & 11.1 & 0.5 & 4.42 & 10.7 & 1.3 & 12.06 \\
\hline
\end{tabular}

Table 9. Basic statistical data of compressive strength of concrete.

\begin{tabular}{ccccccc}
\hline Concrete & $\begin{array}{c}\text { Compressive } \\
\text { Strength after } \\
\text { 14 Days, MPa }\end{array}$ & $\begin{array}{c}\text { Standard } \\
\text { Deviation, } \\
\mathbf{M P a}\end{array}$ & $\begin{array}{c}\text { Variability } \\
\text { Index, } \%\end{array}$ & $\begin{array}{c}\text { Compressive } \\
\text { Strength after } \\
\text { 28 Days, MPa }\end{array}$ & $\begin{array}{c}\text { Standard } \\
\text { Deviation, } \\
\mathbf{M P a}\end{array}$ & $\begin{array}{c}\text { Variability } \\
\text { Index, \% }\end{array}$ \\
\hline Z.I.0 & 68.1 & 2.6 & 3.75 & 76.9 & 4.1 & 5.33 \\
\hline Zk.I.5 & 64.4 & 2.9 & 4.46 & 74.4 & 5.8 & 7.82 \\
Zk.I.10 & 58.6 & 2.6 & 4.47 & 77.2 & 3.5 & 4.59 \\
Zk.I.15 & 62.8 & 2.2 & 3.50 & 78.4 & 4.3 & 5.43 \\
\hline Zc.I.5 & 63.6 & 3.0 & 4.75 & 85.1 & 3.3 & 3.82 \\
Zc.I.10 & 57.1 & 8.4 & 14.67 & 79.8 & 6.3 & 7.92 \\
Zc.I.15 & 59.2 & 3.5 & 5.84 & 75.6 & 4.5 & 5.97 \\
\hline
\end{tabular}

Table 10. Basic statistical characteristics of the composite after thermal shock-200 ${ }^{\circ} \mathrm{C}$.

\begin{tabular}{ccccccc}
\hline Concrete & $\begin{array}{c}\text { Bending } \\
\text { Strength, } \\
\mathbf{M P a}\end{array}$ & $\begin{array}{c}\text { Standard } \\
\text { Deviation, } \\
\mathbf{M P a}\end{array}$ & $\begin{array}{c}\text { Variability } \\
\text { Index, } \%\end{array}$ & $\begin{array}{c}\text { Compressive } \\
\text { Strength, } \\
\mathbf{M P a}\end{array}$ & $\begin{array}{c}\text { Standard } \\
\text { Deviation, } \\
\mathbf{M P a}\end{array}$ & $\begin{array}{c}\text { Variability } \\
\text { Index, \% }\end{array}$ \\
\hline Z.I.0 & 7.1 & 0.8 & 11.13 & 60.5 & 1.8 & 2.88 \\
\hline Zk.I.5 & 7.3 & 0.2 & 2.70 & 61.7 & 2.8 & 4.56 \\
Zk.I.10 & 7.7 & 1.3 & 17.33 & 60.0 & 2.6 & 4.30 \\
Zk.I.15 & 6.4 & 0.9 & 14.26 & 48.8 & 3.0 & 6.13 \\
\hline Zc.I.5 & 7.4 & 0.4 & 5.32 & 51.8 & 2.3 & 4.34 \\
Zc.I.10 & 7.3 & 0.8 & 10.51 & 54.8 & 3.1 & 5.61 \\
Zc.I.15 & 6.7 & 0.3 & 4.67 & 50.2 & 1.4 & 2.69 \\
\hline
\end{tabular}

Table 11. Basic statistical characteristics of the composite after thermal shock-500 ${ }^{\circ} \mathrm{C}$.

\begin{tabular}{ccccccc}
\hline Concrete & $\begin{array}{c}\text { Bending } \\
\text { Strength, } \\
\mathbf{M P a}\end{array}$ & $\begin{array}{c}\text { Standard } \\
\text { Deviation, } \\
\mathbf{M P a}\end{array}$ & $\begin{array}{c}\text { Variability } \\
\text { Index, \% }\end{array}$ & $\begin{array}{c}\text { Compressive } \\
\text { strength, } \\
\mathbf{M P a}\end{array}$ & $\begin{array}{c}\text { Standard } \\
\text { Deviation, } \\
\mathbf{M P a}\end{array}$ & $\begin{array}{c}\text { Variability } \\
\text { Index, \% }\end{array}$ \\
\hline Z.I.0 & 1.4 & 0.2 & 10.04 & 39.8 & 6.5 & 16.25 \\
\hline Zk.I.5 & 3.3 & 1.0 & 30.29 & 58.1 & 6.3 & 10.76 \\
Zk.I.10 & 2.6 & 0.8 & 30.30 & 46.6 & 4.0 & 8.60 \\
Zk.I.15 & 1.7 & 0.2 & 8.94 & 47.2 & 6.6 & 14.03 \\
\hline Zc.I.5 & 2.3 & 0.7 & 29.45 & 38.7 & 8.0 & 16.66 \\
Zc.I.10 & 2.2 & 0.8 & 35.25 & 38.2 & 5.6 & 14.72 \\
Zc.I.15 & 2.7 & 0.4 & 15.84 & 48.4 & 3.7 & 7.55 \\
\hline
\end{tabular}


Table 12. Basic statistical characteristics of the composite after thermal shock- $800{ }^{\circ} \mathrm{C}$.

\begin{tabular}{ccccccc}
\hline Concrete & $\begin{array}{c}\text { Bending } \\
\text { Strength, } \\
\mathbf{M P a}\end{array}$ & $\begin{array}{c}\text { Standard } \\
\text { Deviation, } \\
\mathbf{M P a}\end{array}$ & $\begin{array}{c}\text { Variability } \\
\text { Index, } \%\end{array}$ & $\begin{array}{c}\text { Compressive } \\
\text { Strength, } \\
\mathbf{M P a}\end{array}$ & $\begin{array}{c}\text { Standard } \\
\text { Deviation, } \\
\mathbf{M P a}\end{array}$ & $\begin{array}{c}\text { Variability } \\
\text { Index, \% }\end{array}$ \\
\hline Z.I.0 & 1.0 & 0.2 & 21.23 & 35.3 & 5.2 & 14.80 \\
\hline Zk.I.5 & 0.8 & 0.1 & 14.83 & 38.4 & 3.7 & 9.66 \\
Zk.I.10 & 1.1 & 0.4 & 41.27 & 35.2 & 2.3 & 6.39 \\
Zk.I.15 & 1.4 & 0.2 & 14.53 & 32.0 & 3.6 & 11.32 \\
\hline Zc.I.5 & 1.6 & 0.2 & 14.13 & 37.7 & 2.9 & 7.59 \\
Zc.I.10 & 0.8 & 0.2 & 29.43 & 23.8 & 3.6 & 15.29 \\
Zc.I.15 & 0.8 & 0.2 & 22.57 & 26.4 & 3.2 & 12.09 \\
\hline
\end{tabular}

\subsubsection{Flexural Strength}

A cuboidal beam with a cross section of $40 \times 40$ was subjected to bending, growing loads, until the moment of its destruction. Consequently, the flexural strength was calculated according to Formula (3).

$$
\mathrm{f}_{\mathrm{cf}}=\frac{3 \cdot \mathrm{F} \cdot 1}{2 \cdot \mathrm{d}_{1} \cdot \mathrm{d}_{2}^{2}} \cdot 10,
$$

where:

$\mathrm{f}_{\mathrm{cf}}$-flexural strength (MPa);

$\mathrm{F}$-maximum load in bending test $(\mathrm{kN})$;

l-distribution of sample supports $(\mathrm{cm})$;

$\mathrm{d}_{1}, \mathrm{~d}_{2}$ - dimensions of sample cross-section $(\mathrm{cm})$.

Figure 3 presents results of strength tests in the triaxial bending scheme. The results of testing obtained for each series are the mean arithmetic values received from three measurements.

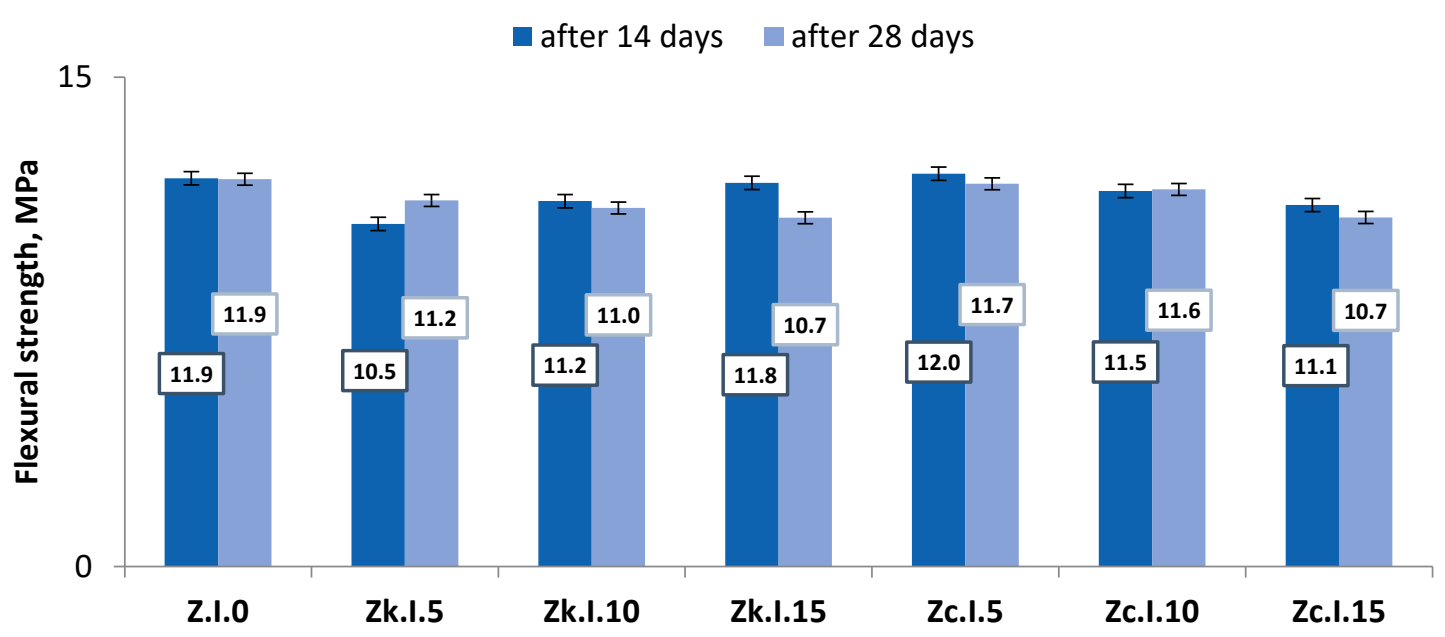

Figure 3. Flexural strength after 14 and 28 days of curing.

Destructive tests were performed at room temperature. Results showed that both samples, modified by aggregate and by glass powder, had a similar strength after 14 and 28 days of curing. The differences in values are insignificant and do not lower significantly strength parameters as compared to reference concrete. The obtained results may be considered satisfactory. The target strength recorded on control samples after 28 days of curing remained within the range of 10.7-11.7 MPa. The highest obtained strength was 11.7 MPa for Zc.I.5, and the lower one was 10.7 MPa for Zk.I.15 and Zc.I.15. The obtained strength values were lower by 0.2 and $1.2 \mathrm{MPa}$, respectively, compared to the reference concrete. 
A slightly lower flexural strength was recorded for concrete with the addition of powder and for glass aggregate. The obtained strength-related results correlated with the Pozzolanic activity of the cullet. A slight impact was observed from the presence of cullet on the decrease of strength after 14 and 28 days of curing compared to the control sample.

The requirements for the tensile strength when bending curbs made of paving stones and concrete curbs were described in [72,73]. The results obtained in the test exceeded $10.5 \mathrm{MPa}$; therefore, they should be considered satisfactory. Similar results concerning the strength of glass-sand concrete were previously described by Du and Tan [74] and Góra and Franus [7].

Table 8 presents the average strength $\mathrm{f}_{\mathrm{cf}}$ along with elementary statistical characteristics.

The variability index for the designed concrete after 14 and 28 days of curing was lower than $10 \%$ (the only exception were Zc.I.15-12.06\%; Zk.I.10-11.07\%). The quality of composite, determined after 14 and 28 days from demoulding, was considered good given concrete Zc.I.15 and Zk.I.10, for which the variability index was lower than $15 \%$. The obtained parameters allowed the presumption that the designed concrete types were of a homogenous nature.

\subsubsection{Compressive Strength}

Results of compressive strength testing of concrete (Figure 4) along with their statistical processing, which comprised the determination of average values, standard deviations, and variability indicators, are presented in Table 9. Tests were carried out for six samples for particular periods of their curing. The testing was conducted at room temperature.

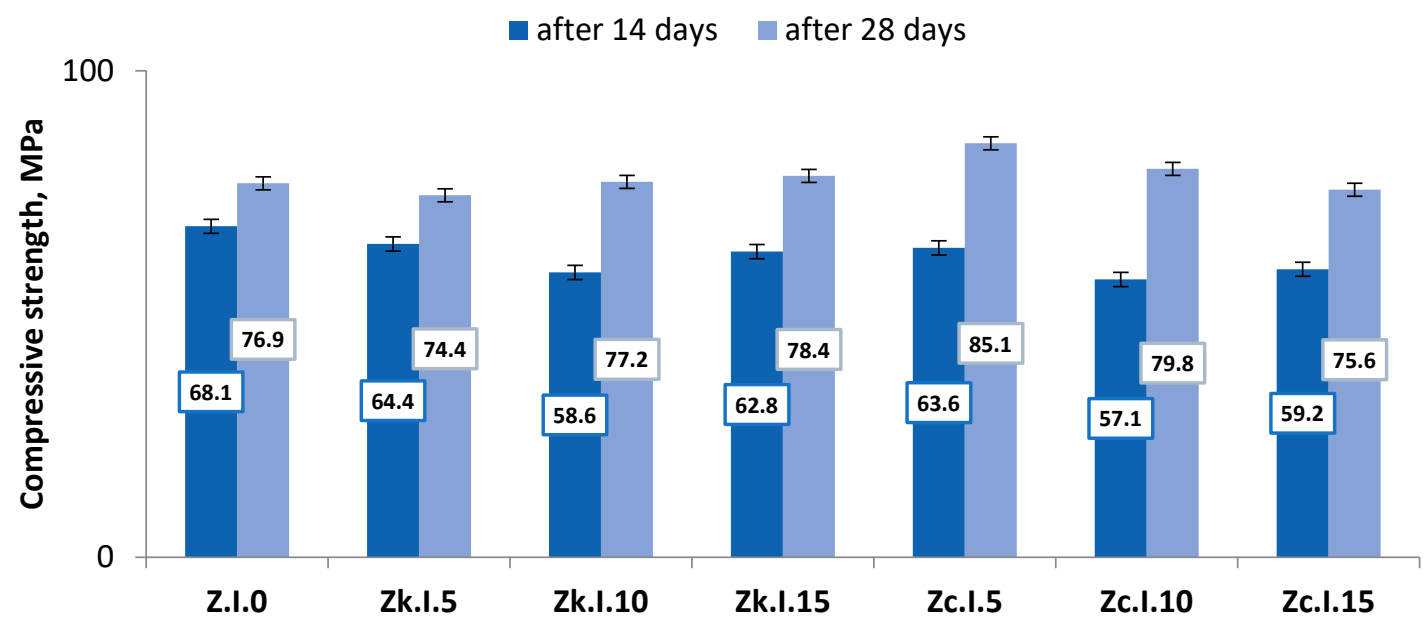

Figure 4. Average compressive strength after 14 and 28 days.

The compressive strength of concrete after 28 days of curing significantly improved thanks to the usage of recyclate, especially when $5 \%$ of cement was replaced by glass powder (Zc.I.5) and $15 \%$ of gravel was replaced by glass aggregate (Zk.I.15). The maximum compressive strength was $85.1 \mathrm{MPa}, 78.4 \mathrm{MPa}$, respectively, which showed an increase by $10.66 \%, 1.95 \%$, as compared to the control sample. The lowest compressive strength was recorded for Zk.I.5 and Zc.I.15. When compared to the control sample, the concrete samples had a slight decrease in strength, by $3.25 \%$ and $1.69 \%$. The usage of waste glass powder amounting to $5 \%$ of the substance increased strength by $8.2 \mathrm{MPa}$.

Results of the compressive tests of concrete after 28 days were found to have a low variability index, below $8 \%$. This proves that this concrete offers very good quality. A downtrend was recorded of the value of the variability index with the increase in strength of concrete over time for Zc.I.5-Zc.I.10-Zc.I.15. On the other hand, in regards to concrete produced with glass aggregate Zk.I.5-Zk.I.10-Zk.I.15, the variability index tended to grow with an increase in strength over time. Figure 5 presents dependencies between the strength of concrete at flexural strength and compressive strength. 


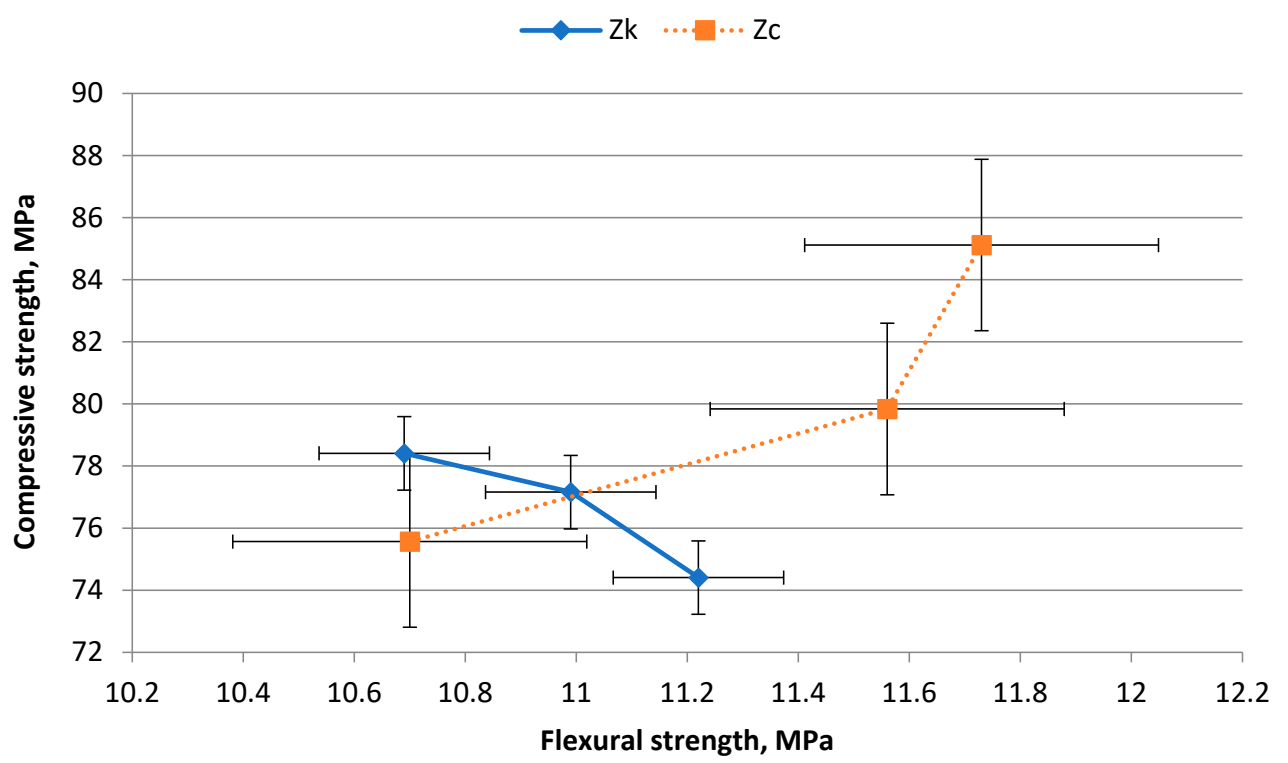

Figure 5. Dependence of flexural strength of concrete on compressive strength.

The continuous line depicts the dependence for the composite produced using recyclate with a grading fraction of $0 / 4 \mathrm{~mm}$. As the content of the recyclate grows, flexural strength tends to grow, while compressive strength tends to decrease. On the other hand, the intermittent line defines the dependence of strength of composite modified by glass powder. Compressive strength and flexural strength grow with an increase of the content of the powder fraction in concrete.

\subsubsection{Strength of Composite under High Temperature Load}

Cuboidal samples were heated up at the temperatures of $200{ }^{\circ} \mathrm{C}, 500{ }^{\circ} \mathrm{C}$, and $800{ }^{\circ} \mathrm{C}$ for $30 \mathrm{~min}$ and tested after their naturally cooling down to ambient temperature. Results of testing, of compressive and tensile strength for samples under the temperature load, are presented in Figures 6 and 7. Results obtained for each of the series are an arithmetic average, from three measurements for flexural strength and from six measurements for compressive strength; moreover, a comparison was made of the standard deviations of results from each series of samples. The basic statistical characteristics are presented in Tables 10-12 for particular periods of their curing.

$\square 20^{\circ} \mathrm{C}=200^{\circ} \mathrm{C} \quad 500^{\circ} \mathrm{C} \quad 800^{\circ} \mathrm{C}$

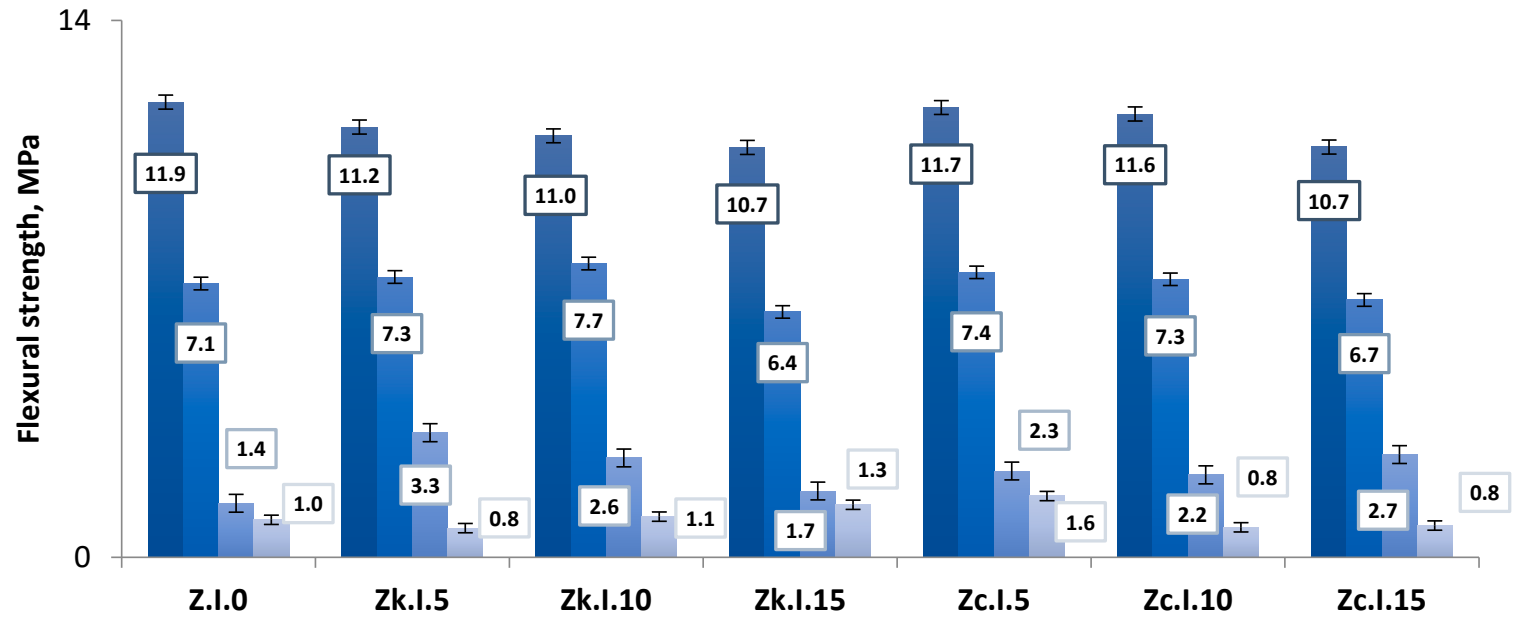

Figure 6. Flexural strength of samples under temperature load. 


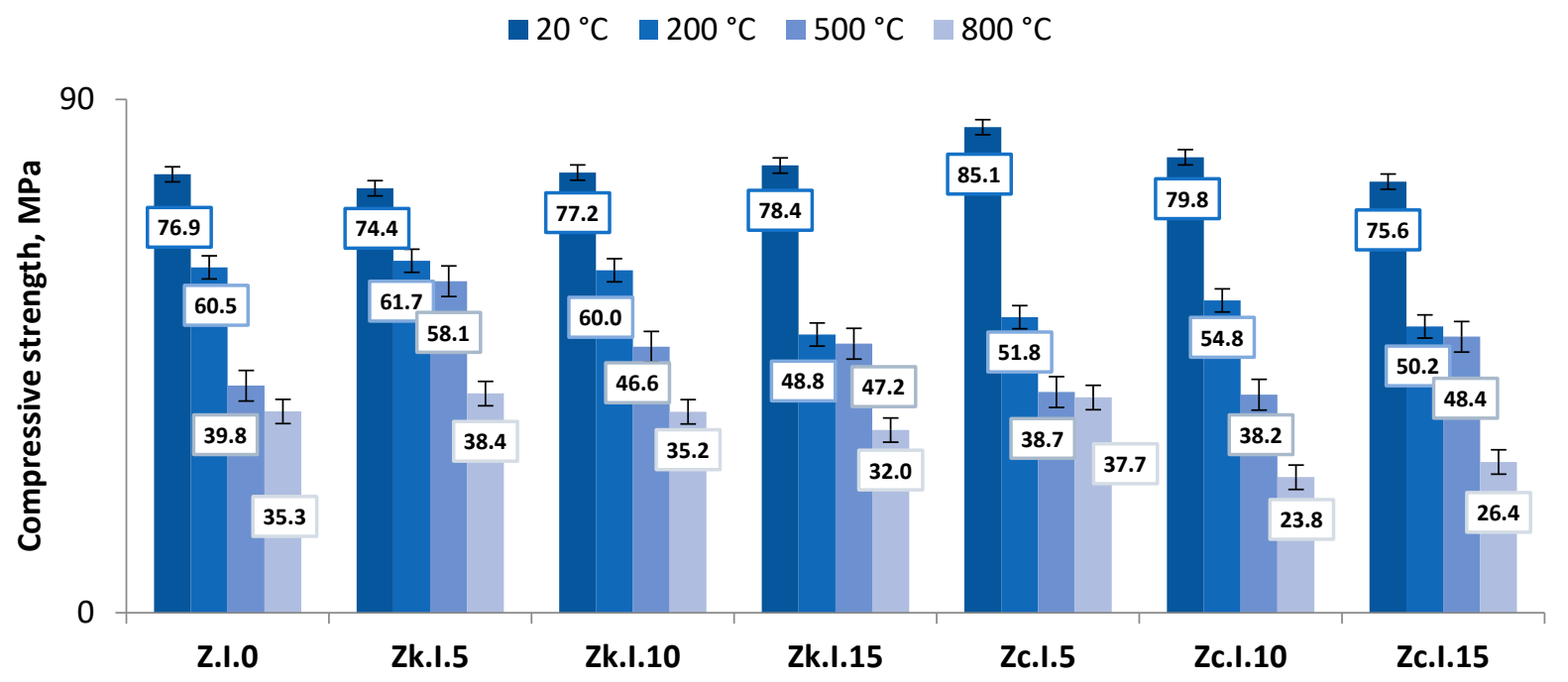

Figure 7. Compressive strength of samples under temperature load.

The above presented diagram shows that, after adding glass recyclate, an improvement was recorded in the results of bending tensile strength, especially for concrete heated at a temperature of $500{ }^{\circ} \mathrm{C}$. The peak value of strength for this temperature was recorded for concrete mix Zk.I.5, for which an increase was ascertained by $43.38 \%$ as compared to the reference concrete. The lowest strength value of $1.7 \mathrm{MPa}$ was recorded for Zk.I.15-slightly higher than the strength of Z.I.0 concrete, by $22.70 \%$. Concrete modified by a $15 \%$ addition of glass powder was characterised by a strength increase by $47.39 \%$, as compared to reference concrete. All types of concrete heated up to $200{ }^{\circ} \mathrm{C}$ achieved a similar mean value of bending tensile strength.

Based on the obtained results, a positive impact was ascertained in regards to high temperatures on the compressive strength of concrete. Samples heated at $500{ }^{\circ} \mathrm{C}$, after 28 days of the hardening period, reached the highest strength limit, equal to $58.1 \mathrm{MPa}$, for the Zk.I.5 mixture, showing an increase of $45.99 \%$, as compared to the control sample. Strength tends to decrease with further replacement of glass aggregate. The lowest strength value was slightly higher than the control sample, by $17.16 \%$, as shown in the above diagram. In regards to mixtures with the addition of glass powder, the highest strength level was recorded for Zc.I.15, which amounted to $48.4 \mathrm{MPa}$, and suggested an increase of $21.55 \%$, as compared to the reference concrete.

The variability index for the designed concrete to be exposed to thermal shock after 28 days of curing was below $10 \%$ for $200{ }^{\circ} \mathrm{C}$. The composite offered very good quality and had a homogenous nature. Concrete heated to the temperature of $500^{\circ} \mathrm{C}$ and $800{ }^{\circ} \mathrm{C}$ still maintained good quality. The obtained results allowed the presumption that adequate component proportions in the mixture were retained. In addition, aggregates play an important role (due to chemical and physical stability) in concrete exposed to high temperatures, as aggregates usually occupy $60-80 \%$ of the volume of concrete.

Concretes made on the basis of alumina cement are used in structures where resistance to temperature is important (refractory concretes). Thanks to the use of ground glass recyclate, it is possible to reduce the total cost of production of concretes resistant to high temperatures. The cost of producing alumina cement is about 4-5 times that of Portland cement. Due to the high cost, the consumption of alumina cement reaches approximately $1 / 1000$ of the consumption of Portland cement [75].

\subsection{Temperature Distribution in the Material}

The tests attempted to assure that temperature distribution was similar to conditions prevailing during a real fire. Samples were heated according to the standard "temperaturetime" curve until the furnace chamber temperature reached $200{ }^{\circ} \mathrm{C}, 500{ }^{\circ} \mathrm{C}$, or $800^{\circ} \mathrm{C}$. 
The concrete bars were heated at the pre-set temperature for a period of $30 \mathrm{~min}$, and then cooled down for $24 \mathrm{~h}$ until ambient temperature was reached. Before heating, a measuring thermoelements ( $\mathrm{CH} 8-\mathrm{CH} 10)$ was fixed to the pilot samples (Figure 8), which enabled the determination of temperature distribution. Regulating thermoelement (RT) was introduced through the posterior wall and was situated in the upper part of the special furnace, PK 1100/5. The testing was conducted in accordance with the standard EN 1991-1-2:2005. The temperature distribution curves are presented in Figure 9. Afterwards, concrete bars were subjected to testing of flexural strength. The remaining sample halves were used to test compressive strength.

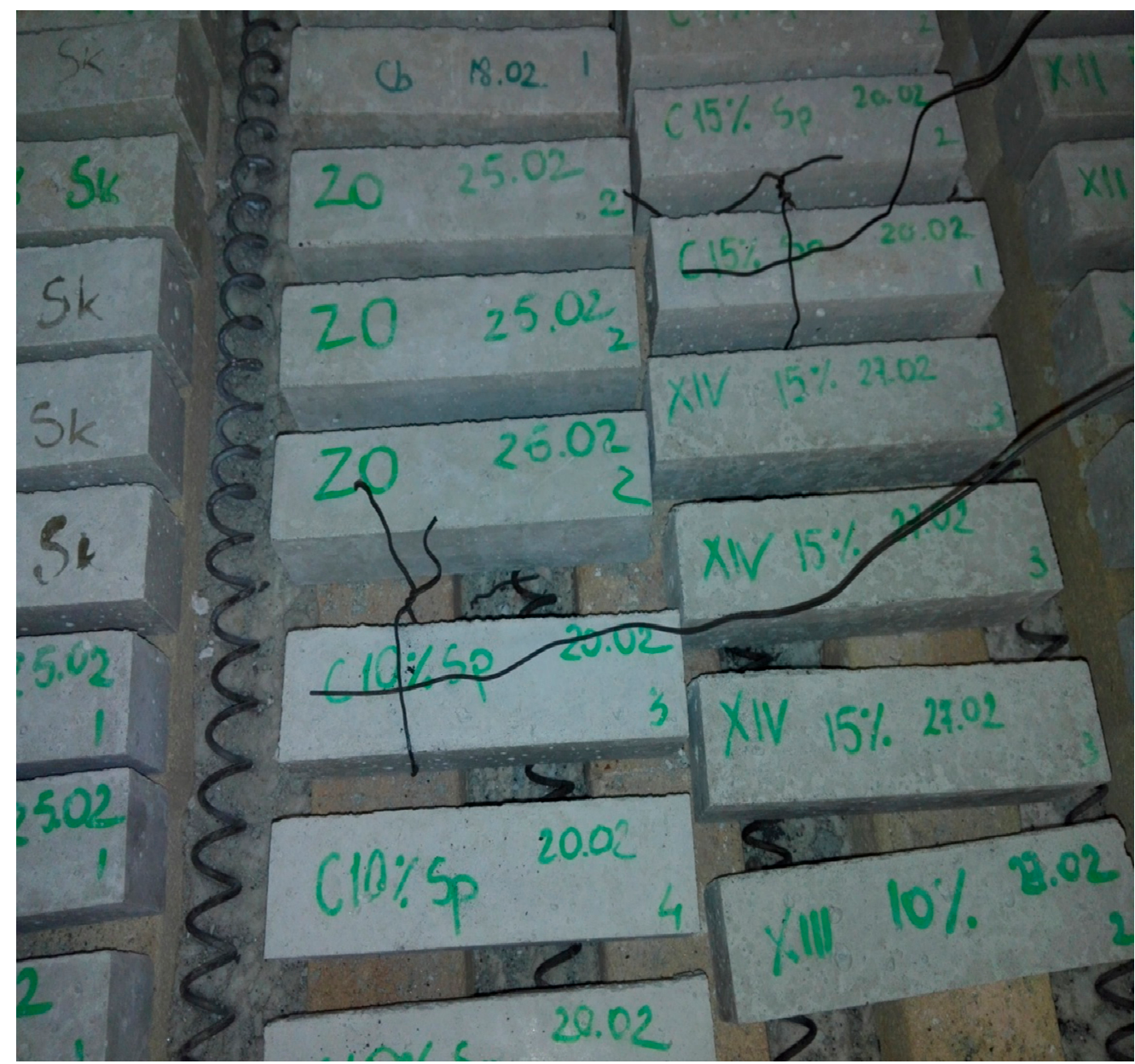

Figure 8. Mounting of thermal elements in the heating chamber before commencement of testing.

Temperature distribution allows ascertaining concrete behaviour in the case of a fire. Heating was applied to concrete bars from particular groups of designed mixtures designated for tests of flexural strength.

The nominal, standard curve time-temperature defines the course of temperature inside a premise in which combustion takes place, of primarily lignin and cellulose materials, such as furniture and paper, described by Formula (4):

$$
\theta=345 \cdot \log (7 t+1)+20 .
$$




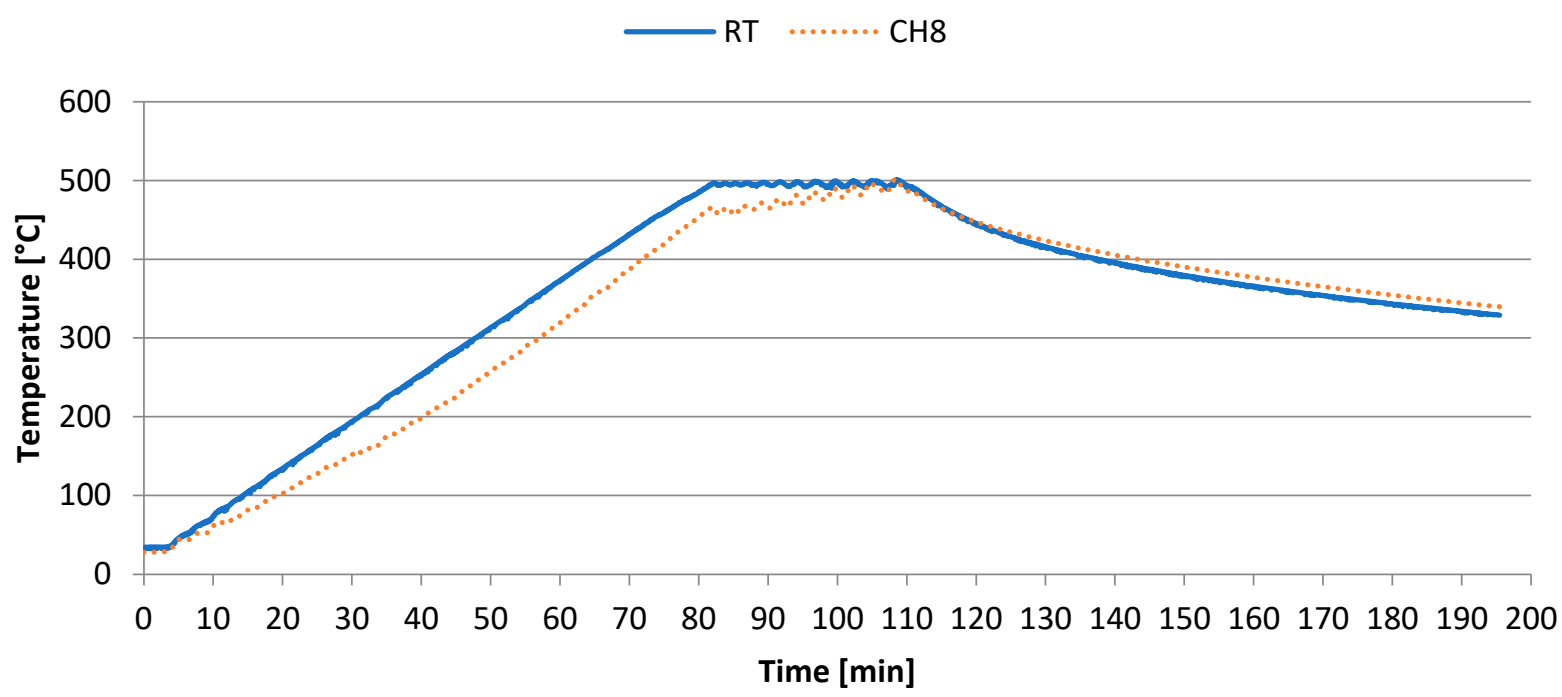

Figure 9. Distribution of temperature in the pilot sample Zc.I.10 heated up to $500^{\circ} \mathrm{C}$.

The accumulation of temperature during a standard fire depicts processes that take place in concrete during the heating process. Once the level of $100{ }^{\circ} \mathrm{C}$ is achieved, the dehydration process commences, i.e., dewatering of components of the cement slurry C-S-H. At a temperature of $350{ }^{\circ} \mathrm{C}$, transformations in gravel commence, while it is $570{ }^{\circ} \mathrm{C}$ in silicate aggregate. The decay of calcium hydroxide $\mathrm{Ca}(\mathrm{OH})_{2}$ takes place between $400{ }^{\circ} \mathrm{C}$ and $600{ }^{\circ} \mathrm{C}$. Silicate concrete is less resistant to the impact of fire, because at $573{ }^{\circ} \mathrm{C}$, quartz transforms from type "a" to type " $b$ ". The decay of calcium carbonate $\mathrm{CaCO}_{3}$ takes place at $700{ }^{\circ} \mathrm{C}-800{ }^{\circ} \mathrm{C}$. In regards to load bearing, concrete heated up to a temperature of $600{ }^{\circ} \mathrm{C}$ should be considered destroyed. Therefore, aggregate, due to its chemical and physical stability, plays an important role in concrete exposed to high temperatures, because $60-80 \%$ of its volume is made of aggregate concrete. In concrete elements, nonlinear temperature distributions occur, as well as stress from thermal deformations [76]. The samples were evenly heated over their entire volume - this may be proven by the point at which the temperatures become balanced. In the cooling down process, a temperature increase takes place in internal layers [31].

\subsection{Analysis of Morphology and Topography of Composite Surface}

The microstructure of concrete was tested with the use of a scanning microscope. The tests were carried out on the surface of cracking of samples, which were destroyed. The results are shown in Figure 10, which reflect the place of study. The samples were tested using the same procedure and the same magnification. The results pertained to analyses of the surface, from the given area, along the pre-set line and a spot analysis.

SEM images did not disclose the occurrence of any significant differences in the morphology and microstructure before and after addition of recyclate to the cement matrix. Mechanical properties of the samples were modified as compared to the control sample. Scratches were ascertained on the surface of the analysed glass material. Data published in [77-79] allow the presumption that composite containing glass addition is less susceptible to deformation due to thermal expansion. 


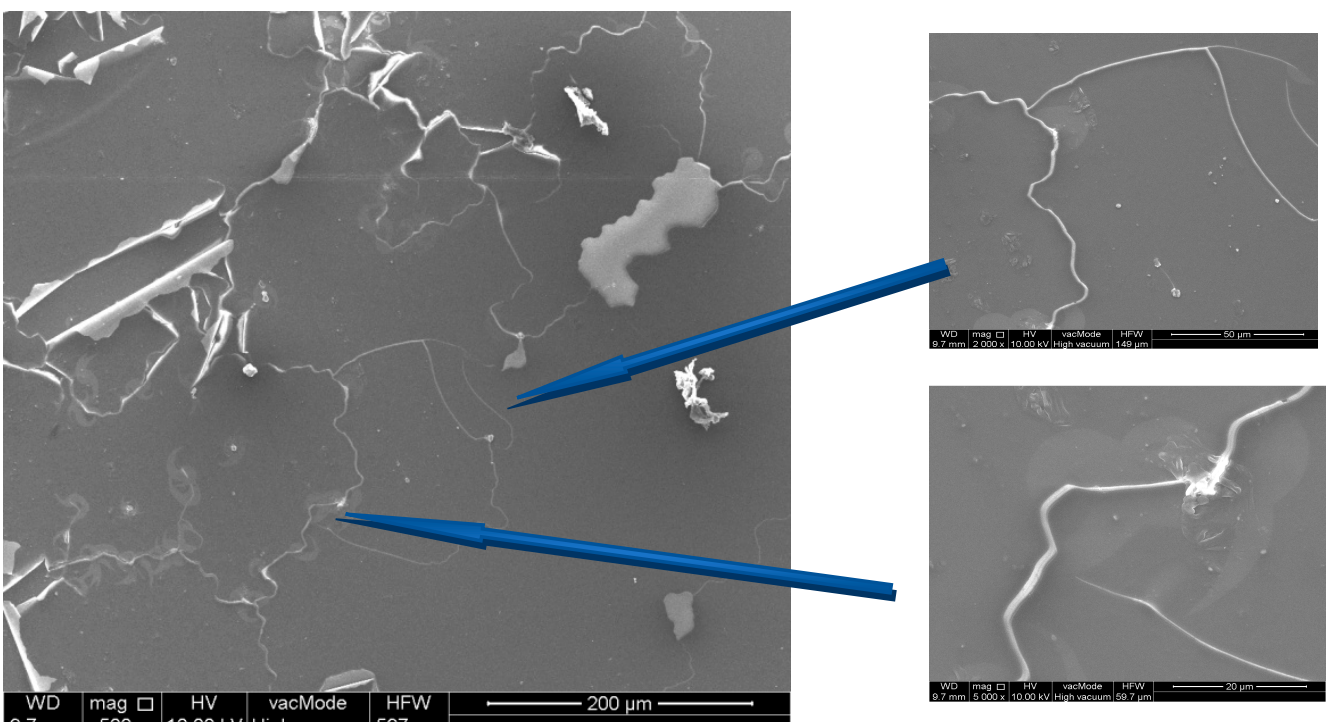

Figure 10. Topography of scratches in the glass material, $20^{\circ} \mathrm{C}$.

\subsection{Elemental Analysis}

Results of the elemental analysis are presented as digitally recorded spectra. This allows making analyses of particular spectra fragments beyond the research device. Identification of elements follows an analysis of all the recorded spectrum peaks. Next, calculations were carried out of the material being tested. This allowed obtaining information concerning the concentration of identified elements as percentage (\%) by weight and \% by atom. Next, the computational error was determined. The obtained results are specified in Table 13. It is also possible to calculate stoichiometry of the oxides (Table 14).

Table 13. Phase composition of a glass sample defined from point $\mathrm{A}, 20^{\circ} \mathrm{C}$.

\begin{tabular}{ccccccc}
\hline $\begin{array}{c}\text { Oxide Com- } \\
\text { position }\end{array}$ & Wt, \% & Mol, \% & K-Ratio & $\begin{array}{c}\text { Excitation } \\
\text { Efficiency } \\
\text { Z }\end{array}$ & $\begin{array}{r}\text { Likelihood } \\
\text { of Absorption } \\
\text { A }\end{array}$ & $\begin{array}{c}\text { Secondary } \\
\text { Fluorescence } \\
\text { F }\end{array}$ \\
\hline $\mathrm{C}_{2} \mathrm{O}$ & 30.11 & 39.95 & 0.0301 & 1.0285 & 0.1617 & 1.0005 \\
$\mathrm{Na}_{2} \mathrm{O}$ & 2.00 & 1.71 & 0.0058 & 0.9466 & 0.4092 & 1.0036 \\
$\mathrm{Al}_{2} \mathrm{O}_{5}$ & 3.09 & 1.23 & 0.0084 & 0.9420 & 0.7053 & 1.0139 \\
$\mathrm{SiO}_{2}$ & 64.34 & 56.85 & 0.2356 & 0.9696 & 0.8080 & 1.0001 \\
$\mathrm{~K}_{2} \mathrm{O}$ & 0.46 & 0.26 & 0.0032 & 0.9181 & 0.9164 & 1.0000 \\
Total & 100.00 & 100.00 & & & & \\
\hline
\end{tabular}

Table 14. Analysis of chemical composition of glass point A, $20^{\circ} \mathrm{C}$.

\begin{tabular}{ccccc}
\hline $\begin{array}{c}\text { Chemical } \\
\text { Compound }\end{array}$ & Net Intensities & $\begin{array}{c}\text { Background } \\
\text { Intensity }\end{array}$ & Intensity Error & $\begin{array}{c}\text { Peak to } \\
\text { Background Ratio } \\
\text { P/B }\end{array}$ \\
\hline CK & 67.40 & 1.21 & 1.87 & 55.91 \\
NaK & 36.51 & 8.76 & 3.04 & 4.17 \\
AlK & 51.98 & 11.33 & 2.51 & 4.59 \\
SiK & 1318.39 & 11.26 & 0.42 & 117.09 \\
KK & 12.49 & 8.33 & 6.52 & 1.50 \\
\hline
\end{tabular}

The analysis of the chemical composition was conducted using the EDS attachment. The percentage of particular oxides were determined from point $\mathrm{A}$ and $\mathrm{B}$ (Figure 11). The oxide composition of glass is characterised by high contents of $\mathrm{SiO}_{2}$ and $\mathrm{C}_{2} \mathrm{O}$ at the level of $64.34 \%$ and $30.11 \%$, respectively. Spectra of the chemical composition are presented in Figure 12. 


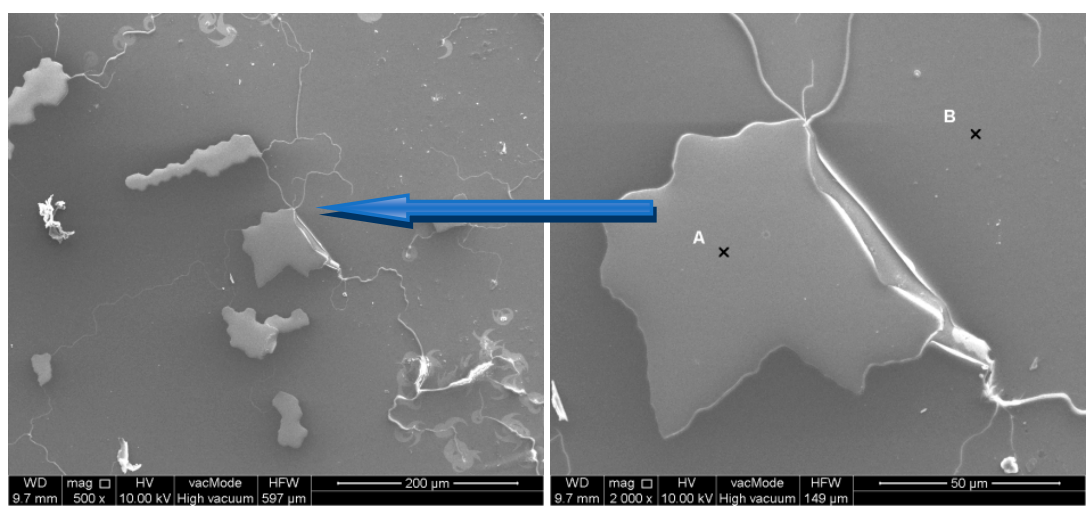

Figure 11. Topography of glass from points $\mathrm{A}$ and $\mathrm{B}, 20^{\circ} \mathrm{C}$.

An analysis of the chemical composition and the obtained spectra confirm the presence of elements comprised by glass recyclate and point to minimum differences in the contents of main components. Peaks were recorded coming from quartz $\left(\mathrm{SiO}_{2}\right)$, potassium oxide $\left(\mathrm{K}_{2} \mathrm{O}\right)$, sodium oxide $\left(\mathrm{Na}_{2} \mathrm{O}\right)$, and aluminium oxide $\mathrm{AL}_{2} \mathrm{O}_{3}$. According to studies described in the literature [77-79], the above mentioned oxides contribute to better mechanical, chemical, and thermal properties of silicate glass. The designed concrete is less susceptible to cracking that may occur after thermal shock.

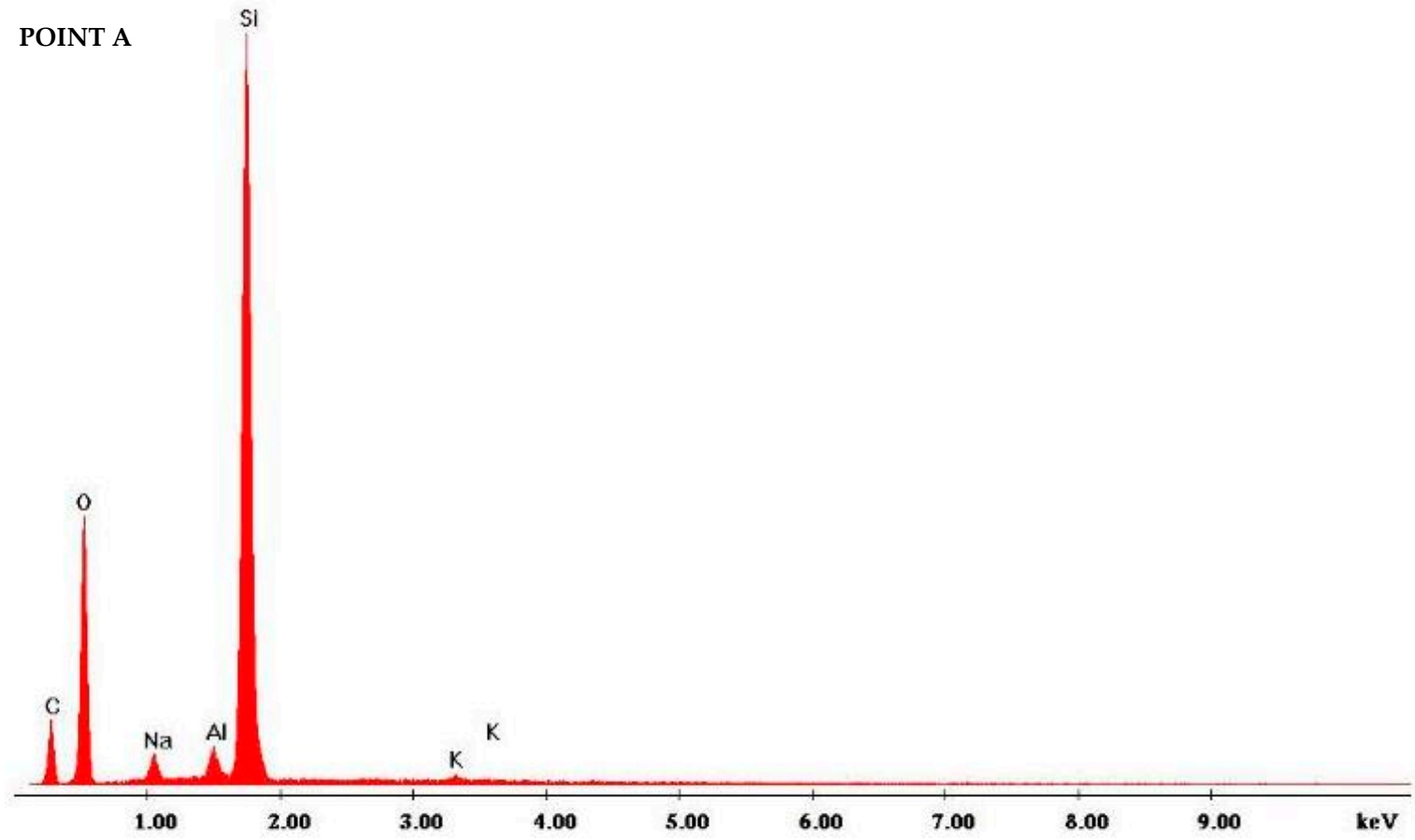

(a)

Figure 12. Cont. 


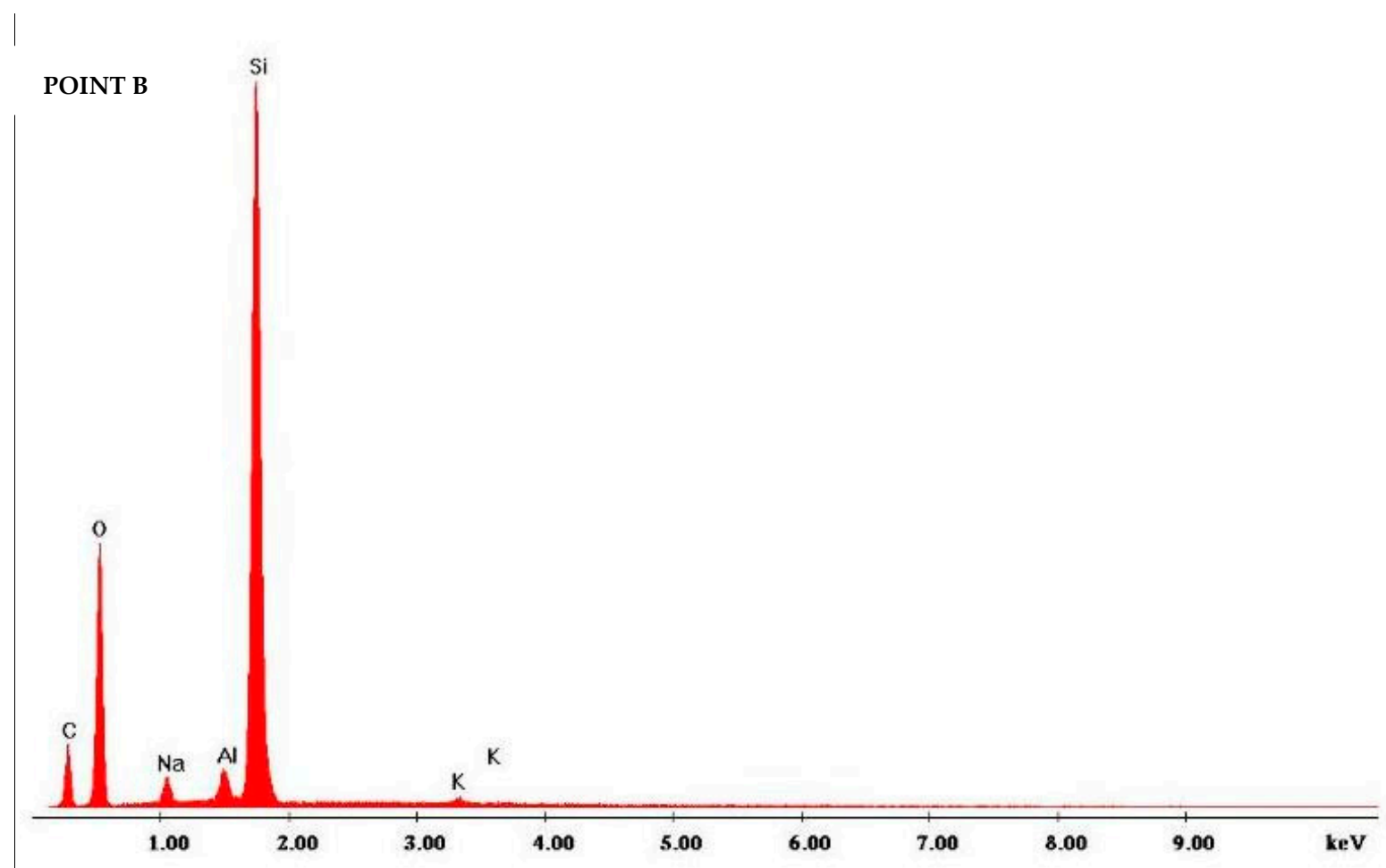

(b)

Figure 12. SEM analysis of glass surface determined from point $A$ and $B(\mathbf{a}, \mathbf{b}), 20^{\circ} \mathrm{C}$.

\section{Conclusions}

An analysis of the obtained results of the experiments allowed the formulation of the following conclusions:

1. If glass powder is used as a substitute for cement, after 28 days of curing, concrete Zc.I.5 was found to have the biggest increase of compressive strength by approximately $10 \%$ with the addition of cullet by approximately $5 \%$, as compared to the control sample.

2. Comparable parameters were obtained from bending tensile strength, after 14 and 28 days of curing with the control trial. This proves the Pozzolanic reactivity of cullet.

3. The correlation between the average compressive strength and the average flexural strength is significant. In regards to concrete $Z \mathrm{k}$, a decrease in compressive strength was recorded, as well as an increase in flexural strength, with an increase of the amount of cullet used in concrete. Meanwhile, for concrete $\mathrm{Zc}$, the compressive strength and the flexural strength grew as the amount of recyclate in concrete increased.

4. The obtained results provide proof that cullet positively affects the concrete strength in situations of a fire. Flexural strength, for all concrete samples heated up to temperature of $500{ }^{\circ} \mathrm{C}$, considerably grew; concrete produced with the use of glass powder $\mathrm{Zc}$ increased to at least $52 \%$. If $5 \%$ of fine glass cullet was added, concrete Zk.I.5 had a maximum strength equalling to $3.25 \mathrm{MPa}$, proving a significant increase $(130 \%)$ in strength as compared to the basic sample. Tests of compressive strength of concrete types subjected to temperature loads of $500{ }^{\circ} \mathrm{C}$, in which cullet was used as a substitute for aggregate, showed that an approximate increase was achieved by $46 \%-17 \%-18 \%$ for Zk.I.5-Zk.I.10-Zk.I.15, respectively.

5. The level of compressive strength determined for all samples modified by glass aggregate, heated up to $800{ }^{\circ} \mathrm{C}$, was slightly higher (or similar) in strength as compared to the control trial. 
6. Concentrations of elements in the tested material remained within admissible limits.

7. Waste consisting of cullet is fully valuable material that can be reused in the production of concrete. Recyclate does not undergo biodegradation, and may be used both as substitute of fine aggregate and of cement.

To date, research shows that an insignificant replacement of cement or fine aggregate with glass waste containing finer fractions may prove advantageous; however, the achieved results continue to be rather contradictory, which shows that the optimum mixture formula has not been established yet. The topic at hand requires further long-term studies to allow an in-depth evaluation of the feasibility of using cullet as a recycling aggregate for the production of unconventional concrete.

Author Contributions: Conceptualization, A.P.; methodology, A.P., P.O. and J.S.; software, A.P.; validation, A.P.; formal analysis, A.P.; investigation, A.P. and J.S.; resources, A.P., P.O. and J.S.; data curation, A.P. and J.S.; writing-original draft preparation, A.P.; writing-review and editing, P.O. and J.S.; visualization, A.P.; supervision, P.O. and J.S.; project administration, A.P.; funding acquisition, M.P. and A.P. All authors have read and agreed to the published version of the manuscript.

Funding: This research was funded by National Centre for Research and Development as part of the project: training simulator in the use of technical fire protection systems supporting the evacuation of people from buildings DOB-BIO9/16/01/2018.

Conflicts of Interest: The authors declare no conflict of interest.

\section{References}

1. Everything about Recycling. Glass Recycling. Available online: https://www.oostdam.pl/recykling-szkla/ (accessed on 30 March 2020).

2. Waste Statistic. Eurostat. Statistic Explained. Available online: https://ec.europa.eu/eurostat/statistics-explained/index.php? title=Waste_statistics / pl (accessed on 15 November 2019).

3. Kaza, S.; Yao, L.; Bhada-Tata, P.; Van Woerden, F. What A Waste 2.0: A Global Snapshot of Solid Waste Management To 2050; World Bank Group: Washington, DC, USA, 2018; pp. 17-38.

4. Record Collection of Glass Containers for Recycling Hits 76\% in the EU. Available online: https://feve.org/record-collection-ofglass-containers-for-recycling-hits-76-in-the-eu/ (accessed on 20 February 2021).

5. Abramowicz, M.; Adamski, R.G. Bezpieczeństwo Pożarowe Budynków [Fire Safety of Buildings], Part 1; Main School of Fire Service: Warsaw, Poland, 2002; pp. 59-72.

6. Meda, A.; Rinaldi, Z.; Spagnuolo, S.; De Rivaz, B.; Giamundo, N. Hybrid precast tunnel segments in fiber reinforced concrete with glass fiber reinforced bars. Tunn. Undergr. Space Technol. 2019, 86, 100-112. [CrossRef]

7. Góra, J.; Franus, M.; Barnat-Hunek, D.; Franus, W. Utilization of Recycled Liquid Crystal Display (LCD) Panel Waste in Concrete. Materials 2019, 12, 2941. [CrossRef] [PubMed]

8. He, Z.-H.; Zhan, P.-M.; Du, S.-G.; Liu, B.-J.; Yuan, W.-B. Creep behavior of concrete containing glass powder. Compos. Part B Eng. 2019, 166, 13-20. [CrossRef]

9. Liu, H.; Shi, J.; Qu, H.; Ding, D. An investigation on physical, mechanical, leaching and radiation shielding behaviors of barite concrete containing recycled cathode ray tube funnel glass aggregate. J. Constr. Build. Mater. 2019, 201, 818-827. [CrossRef]

10. Meddah, M.S. Use of Waste Window Glass as Substitute of Natural Sand in Concrete Production. IOP Conf. Ser. Mater. Sci. Eng. 2019, 603, 32011. [CrossRef]

11. Panedpojaman, P.; Tonnayopas, D. Rebound hammer test to estimate compressive strength of heat exposed concrete. J. Constr. Build. Mater. 2018, 172, 387-395. [CrossRef]

12. Hyeongi, L.; Asad, H.; Muhammad, U.; Jongsung, S.; Hongseob, O. Performance evaluation of concrete incorporating glass powder and glass sludge wastes as supplementary cementing material. J. Clean. Prod. 2018, 170, 683-693. [CrossRef]

13. Kim, I.S.; Choi, S.Y.; Yang, E.I. Evaluation of durability of concrete substituted heavyweight waste glass as fine aggregate. J. Constr. Build. Mater. 2018, 184, 269-277. [CrossRef]

14. Islam, G.S.; Rahman, M.H.; Kazi, N. Waste glass powder as partial replacement of cement for sustainable concrete practice. Int. J. Sustain. Built Environ. 2017, 6, 37-44. [CrossRef]

15. Zhang, L.; Zhang, Y.; Liu, C.; Liu, L.; Tang, K. Study on microstructure and bond strength of interfacial transition zone between cement paste and high-performance lightweight aggregates prepared from ferrochromium slag. J. Constr. Build. Mater. 2017, 142, 31-41. [CrossRef]

16. Biolzi, L.; Cattaneo, S.; Crespi, P.; Giordano, N. Damage in glass-concrete composite panels. J. Constr. Build. Mater. 2016, 116, 235-244. [CrossRef]

17. Omran, A.; Tagnit-Hamou, A. Performance of glass-powder concrete in field applications. J. Constr. Build. Mater. 2016, 109, 84-95. [CrossRef] 
18. Spiesz, P.; Rouvas, S.; Brouwers, H.J.H. Utilization of waste glass in translucent and photocatalytic concrete. J. Constr. Build. Mater. 2016, 128, 436-448. [CrossRef]

19. Mörtel, H.; Fuchs, F. Recycling of windshield glasses in fired bricks industry. Key Eng. Mater. 1997, 132-136, 2268-2271. [CrossRef]

20. Matteucci, F.; Dondi, M.; Guarini, G. Effect of soda-lime glass on sintering and technological properties of porcelain stoneware tiles. Ceram. Int. 2002, 28, 873-880. [CrossRef]

21. Tucci, A.; Esposito, L.; Rastelli, E.; Palmonari, C.; Rambaldi, E. Use of soda-lime scrap-glass as a fluxing agent in a porcelain stoneware mix. J. Eur. Ceram. Soc. 2004, 24, 83-92. [CrossRef]

22. Pontikes, Y.; Christogerou, A.; Angelopoulos, G.N.; Esposito, L.; Tucci, A. On the addition of soda-lime scrap glass for the production of heavy clay ceramics. Ceramurg. Ceram. Acta 2004, 34, 199-206.

23. Dondi, M.; Guarini, G.; Raimondo, M.; Zanelli, C. Recycling PC and TV waste glass in clay bricks and roof tiles. Waste Manag. 2009, 29, 1945-1951. [CrossRef]

24. Palmonari, C.; Tenaglia, A. Manufacture of heavy-clay products with the addition of residual sludges from other ceramic industries. Miner. Petrogr. Acta 1985, 29, 547-562.

25. Andreola, F.; Barbieri, L.; Corradi, A.; Lancellotti, I. CRT glass state of the art. A case study: Recycling in ceramic glazes. J. Eur. Ceram. Soc. 2007, 27, 1623-1629. [CrossRef]

26. Shi, C.; Wu, Y.; Shao, Y.; Riefler, C. Alkali-aggregate reaction of concrete containing ground glass powder. In Proceedings of the 12th International Conference on AAR in Concrete, Beijing, China, 15-19 October 2004; pp. 789-795.

27. Kim, K.; Kim, K.; Hwang, J. LCD waste glass as a substitute for feldspar in the porcelain sanitary ware production. Ceram. Int. 2015, 141, 7097-7102. [CrossRef]

28. Najduchowska, M.; Różycka, K.; Rolka, G. Ocena możliwości wykorzystania stłuczki szklanej w przemyśle budowlanym w aspekcie jej wpływu na środowisko naturalne [Assessment of the feasibility of using cullet in the construction industry from the viewpoint of its impact on the natural environment]. Inst. Ceram. Mater. Bud. 2014, 17, 46-56.

29. Drzymała, T.; Zegardło, B.; Tofiło, P. Properties of Concrete Containing Recycled Glass Aggregates Produced of Exploded Lighting Materials. Materials 2020, 13, 226. [CrossRef]

30. Powęzka, A.; Szulej, J.; Ogrodnik, P. Reuse of Heat Resistant Glass Cullet in Cement Composites Subjected to Thermal Load. Materials 2020, 13, 4434. [CrossRef]

31. Powęzka, A.; Szulej, J.; Ogrodnik, P. Effect of High Temperatures on the Impact Strength of Concrete Based on Recycled Aggregate Made of Heat-Resistant Cullet. Materials 2020, 13, 465. [CrossRef]

32. Powęzka, A.; Ogrodnik, P.; Biedugnis, S.; Szulej, J. Assessment of selected parameters of concrete composite containing recyclate obtained from fire-resistant cullet. J. Phys. Conf. 2019, 1398, 12011. [CrossRef]

33. Degirmenci, N.; Yilmaz, A.; Cakir, O.A. Utilization of waste glass as sand replacement in cement mortar. Indian J. Eng. Mater. Sci. 2011, 18, 303-308.

34. Terro, M.J. Properties of concrete made with recycled crushed glass at elevated temperatures. Build. Environ. 2006, 41, 633-639. [CrossRef]

35. Schwarz, N.; Cam, H.; Neithalath, N. Influence of a fine glass powder on the durability characteristics of concrete and its comparison to fly ash. Cem. Concr. Compos. 2008, 30, 486-496. [CrossRef]

36. Nassar, R.; Soroushian, P. Strength and durability of recycled aggregate concrete containing milled glass as partial replacement for cement. Constr. Build. Mater. 2012, 29, 368-377. [CrossRef]

37. Aly, M.; Hashmi, M.S.J.; Olabi, A.G.; Messeiry, M.; Abadir, E.F.; Hussain, A.I. Effect of colloidal nano-silica on the mechanical and physical behaviour of waste-glass cement mortar. Mater. Des. 2012, 33, 127-135. [CrossRef]

38. Pawluczuk, E.; Kalinowska-Wichrowska, K.; Bołtryk, M.; Jiménez, J.R.; Fernández, M. The Influence of Heat and Mechanical Treatment of Concrete Rubble on the Properties of Recycled Aggregate Concrete. Materials 2019, 12, 367. [CrossRef] [PubMed]

39. Omran, A.F.; Etienne, D.; Harbec, D.; Tagnit-Hamou, A. Long-term performance of glass-powder concrete in large-scale field applications. Constr. Build. Mater. 2017, 135, 43-58. [CrossRef]

40. Nowak, A.; Tora, B.; Tejchman, Z.; Peszko, B. Badanie możliwości utylizacji pozostałości po recyclingu odpadów szklanych w produkcji kruszywa piaskowego [Study of possibilities of using remnants from recycling of glass waste in the production of sand aggregate]. Gór. Geoinż. 2008, 34, 203-206.

41. Chyłek, E.K. Nowa strategia Komisji Europejskiej dotyczące biogospodarki i gospodarki wewnętrznej o obiegu zamkniętym [New strategy of the European Commission concerning bio-economy and closed loop internal economy]. Pol. J. Agron. 2016, 25, 3-12.

42. Liu, G.; Florea, M.V.A.; Brouwers, H.J.H. Performance evaluation of sustainable high strength mortars incorporating high volume waste glass as binder. Constr. Build. Mater. 2019, 202, 574-588. [CrossRef]

43. Shi, C.; Zheng, K. A review on the use of waste glasses in the production of cement and concrete. Resour. Conserv. Recycl. 2007, 52, 234-247. [CrossRef]

44. Du, H.; Tan, K.H. Properties of high-volume glass powder concrete. Cem. Concr. Compos. 2017, 75, 22-29. [CrossRef]

45. Lu, J.X.; Zhan, B.J.; Duan, Z.H.; Poon, C.S. Using glass powder to improve the durability of architectural mortar prepared with glass aggregates. Mater. Des. 2017, 135, 102-111. [CrossRef] 
46. Ramakrishnan, K.; Pugazhmani, G.; Sripragadeesh, R.; Muthu, D.; Venkatasubramanian, C. Experimental study on the mechanical and durability properties of concrete with waste glass powder and ground granulated blast furnace slag as supplementary cementitious materials. Constr. Build. Mater. 2017, 156, 739-749. [CrossRef]

47. Omrane, M.; Kenai, S.; Kadri, E.H.; Aït-Mokhtar, A. Performance and durability of self-compacting concrete using recycled concrete aggregates and natural pozzolan. J. Clean. Prod. 2017, 165, 415-430. [CrossRef]

48. Soliman, N.A.; Tagnit-Hamou, A. Partial substitution of silica fume with fine glass powder in UHPC: Filling the micro gap. Constr. Build. Mater. 2017, 139, 374-383. [CrossRef]

49. Aliabdo, A.A.; Elmoaty, A.E.M.A.; Aboshama, A.Y. Utilization of waste glass powder in the production of cement and concrete. Constr. Build. Mater. 2016, 24, 866-877. [CrossRef]

50. Afshinnia, K.; Rangaraju, P.R. Impact of combined use of ground glass powder and crushed glass aggregate on selected properties of Portland cement concrete. Constr. Build. Mater. 2016, 117, 263-272. [CrossRef]

51. Kushartomo, W.; Bali, I.; Sulaiman, B. Mechanical Behavior of Reactive Powder Concrete with Glass Powder Substitute. Procedia Eng. 2015, 125, 617-622. [CrossRef]

52. Bhandari, P.S.; Tajne, K.M. Use of waste glass in cement mortar. Int. J. Civ. Struct. Eng. 2013, 3, 704-711. [CrossRef]

53. Gesoglu, M.; Güneyisi, E.; Öznur, H.; Taha, I.; Taner, M. Failure characteristics of self-compacting concretes made with recycled aggregates. J. Constr. Build. Mater. 2015, 98, 334-344. [CrossRef]

54. AL-Zubaid, A.B.; Shabeeb, K.M.; Ali, A.I. Study the Effect of Recycled Glass on The Mechanical Properties of Green Concrete. Energy Procedia 2017, 119, 680-692. [CrossRef]

55. Zheng, K. Recycled glass concrete. In Eco-Efficient Concrete; Woodhead Publishing: Cambridge, UK, 2013 ; pp. $241-270$.

56. De Castro, S.; de Brito, J. Evaluation of the durability of concrete made with crushed glass aggregates. J. Clean. Prod. 2013, 41, 7-14. [CrossRef]

57. Wang, H.Y.; Zeng, H.H.; Wu, J.Y. A study on the macro and micro properties of concrete with LCD glass. Constr. Build. Mater. 2014, 50, 664-670. [CrossRef]

58. Wang, H.Y.; Huang, W.L. Durability of self-consolidating concrete using waste LCD glass. Constr. Build. Mater. 2010, 6, 1008-1013. [CrossRef]

59. Rutkowska, G.; Wichowski, P.; Fronczyk, J.; Franus, M.; Chalecki, M. Use of fly ashes from municipal sewage sludge combustion in production of ash concretes. Constr. Build. Mater. 2018, 188, 874-883. [CrossRef]

60. Siddique, R.; Cachim, P. Waste and Supplementary Cementitious Materials in Concrete: Characterisation, Properties and Applications; Woodhead Publishing: Duxford, UK, 2018.

61. Jamroży, Z. Beton i Jego Technologie [Concrete and Its Technologies], 2nd ed.; Wydawnictwo Naukowe PWN: Warszawa, Poland, 2015.

62. Kucharska, L. W/C-wskaźnik wpływu warstwy przejściowej na właściwości mechaniczne betonów zwykłych i BWW i ich podział [W/C-index of the impact of the transient layer on mechanical properties of ordinary and BWW concrete and their division]. Cem. Wapno Beton 1999, 2, 39-45.

63. Kuznetsova, T.V. High aluminate cement production in Russia. Cem. Wapno Beton 2008, 75, 291-298.

64. George, C.M.; Montgomery, R.G.J. Calcium aluminate cement concrete: Durability and conversion-A fresh look at an old subject. Mater. Constr. 1992, 42, 33-50. [CrossRef]

65. Ogrodnik, P.; Szulej, J. The impact of aeration of concrete based on ceramic aggregate, exposed to high temperatures, on its strength parameters. Constr. Build. Mater. 2017, 157, 909-916. [CrossRef]

66. Zegardło, B.; Szelag, M.; Ogrodnik, P.; Bombik, A. Physico-mechanical properties and microstructure of Polymer Concrete with Recycled Glass Aggregate. Materials 2018, 11, 1213. [CrossRef]

67. Wiłun, Z. Zarys Geotechniki [Overview of Geotechnics], 10th ed.; Wydawnictwa Komunikacji i Łaczności: Warsaw, Poland, 2020.

68. ASTM D 2487-06. Standard Practice for Classification of Soils for Engineering Purposes (Unified Soil Classification System); ASTM International: West Conshohocken, PA, USA, 2006; Available online: www.astm.org (accessed on 16 February 2021). [CrossRef]

69. EN 1997-2. Eurocode 7. Geotechnical Design. Part 2: Ground Investigation and Testing; European Committee for Standardization, EU: Brussels, Belgium, 2007; Available online: www.phd.eng.br (accessed on 16 February 2021).

70. Sas, W.; Miszkowska, A.; Głuchowski, A. Impact of crushing vulnerability on recycled concrete aggregate physical and mechanical properties. Sci. Rev. Eng. Environ. Sci. 2015, 67, 40-53.

71. Patakiewicz, M.A.; Zabielska-Adamska, K. Coefficient of curvature and compaction parameters for non-cohesive soils with bimodal grain size distribution. Acta Sci. Pol. Archit. 2013, 12, 111-123.

72. EN 1338. Concrete Paving Blocks. Requirements and Test Methods; BSI: London, UK, 2003.

73. EN 1339. Concrete Paving Flags. Requirements and Test Methods; BSI: London, UK, 2003.

74. Du, H.; Tan, K.H. Concrete with recycled glass as fine aggregates. ACI Mater. J. 2014, 111, 47-58.

75. Stinnessen, I.; Buhr, A.; Kockegey-Lorenz, R.; Racher, R. High Purity Calcium Aluminate Cements, Production and Properties. Available online: https://almatis-umbraco.azurewebsites.net/media/3985/high_purity_calcium-aluminate-cements_ production_and_properties.pdf (accessed on 9 May 2021).

76. Powęzka, A. Nośność Elementów Konstrukcyjnych Żelbetowych Poddanych Zginaniu W Sytuacji Ogniowej [Load Bearing Capacity of Reinforced Concrete Structural Elements Subjected to Bending in Fire Situations]; Computational Study Based on Eurocodes and on the Available Empirical Research; Main School of Fire Service, Institute of Fire Security Engineering: Warsaw, Poland, 2011. 
77. Gawlicki, M.; Bobrowski, A.; Spyrka, J. Immobilizacja metali ciężkich w zaczynach cementowych [Immobilisation of heavy metals in cement slurry]. Pol. Com. Nauk Ceramic. PAN 1994, 46, 237-241.

78. Diamond, S. The microstructures of cement paste in concrete. In Proceedings of the 8th International Congress on the Chemistry of Cement, Rio de Janeiro, Brazil, 22-27 September 1986; pp. 2-9.

79. Zatryb, G.; Podhorodecki, A.; Misiewicz, J.; Cardin, J.; Gourbilleau, F. On the nature of the stretched exponential photoluminescence decay for silicon nanocrystals. Nanoscale Res. Lett. 2011, 6, 106. [CrossRef] 